\title{
Complete microglia deficiency accelerates prion disease without enhancing
}

\section{CNS prion accumulation}

Short title: Prion disease in the complete absence of microglia

Authors: Barry M. Bradford ${ }^{1 \#}$, Lynne I. McGuire ${ }^{1}$, David A. Hume ${ }^{2}$, Clare Pridans ${ }^{3,4}$ \& Neil A. Mabbott $^{1 \#}$

Affiliations:

1. The Roslin Institute and R(D)SVS, University of Edinburgh, Easter bush campus, Midlothian, EH25 9RG, UK.

2. Mater Research Institute-University of Queensland, Translational Research Institute, Woolloongabba, QLD, 4102, Australia.

3. Simons Initiative for the Developing Brain, Centre for Discovery Brain Sciences, University of Edinburgh, Hugh Robson Building, George Square, Edinburgh, EH8 9XD, UK.

4. Centre for Inflammation Research, The Queen's Medical Research Institute, Edinburgh BioQuarter, 47 Little France Crescent, Edinburgh, EH16 4TJ, UK

\#Address correspondence to:

Barry M. Bradford barry.bradford@roslin.ed.ac.uk

Neil A. Mabbott neil.mabbott@roslin.ed.ac.uk 
Prion diseases are transmissible, neurodegenerative disorders to which there are no cures. Previous studies show that reduction of microglia accelerates prion disease and increases the accumulation of prions in the brain, suggesting that microglia provide neuroprotection by phagocytosing and destroying prions. In $\operatorname{Csf} 1 r^{\triangle F I R E}$ mice, the deletion of an enhancer within Csf1r specifically blocks microglia development, however, their brains develop normally with none of the deficits reported in other microglia-deficient models. $C s f 1 r^{\triangle F I R E}$ mice were used as a refined model to study the impact of microglia-deficiency on CNS prion disease. Although Csf1 $r^{\triangle F I R E}$ mice succumbed to prion disease much earlier than wild-type mice, the accumulation of prions in their brains was reduced. Instead, astrocytes displayed earlier, nonpolarized reactive activation with enhanced synaptic pruning and unfolded protein responses. Our data suggest that rather than engulfing and degrading prions, the microglia instead provide neuroprotection and restrict the harmful activities of reactive astrocytes. 


\section{Introduction}

The parenchymal macrophages of the central nervous system (CNS) are known as microglia (Rio-Hortega, 1919) and their proliferation and survival is dependent upon signaling via the colony stimulating factor 1 receptor (CSF1R) (Hume et al., 2020). Microglia have been attributed essential functions in the development and homeostasis of the CNS including synaptogenesis, neurogenesis and maturation of neuronal circuits (Prinz et al., 2019).

40 However, mice with a Csf1r hypomorphic mutation (Csf1 $r^{\Delta \mathrm{FIRE}}$ ) (Rojo et al., 2019), with conditional Csf1r deletion (using Iba1-cre) (Nakayama et al., 2018) and rats with a Csf1r null mutation (Pridans et al., 2018) each lack microglia entirely but have normal CNS development. These findings indicate that developmental roles of microglia are redundant. There is much greater evidence that microglia contribute to neuropathology (Prinz et al., 2019). Neurodegenerative diseases associated with mutations in microglia-expressed genes such as CSF1R in humans have been referred to as microgliopathies (Hume et al., 2020).

Prion diseases, or transmissible spongiform encephalopathies, are fatal progressive neurodegenerative diseases to which there are no cures. Infectious prions are considered to result from the misfolding of the host's cellular prion protein $\left(\operatorname{Pr} \mathrm{PC}^{\mathrm{C}}\right)$ into an abnormal diseaseassociated isoform ( $\mathrm{PrP}^{\mathrm{Sc}}$ ) (Prusiner, 1982). The accumulation of $\mathrm{PrP}^{\mathrm{Sc}}$ within the brain is accompanied by the impairment of neuronal dendritic spines and synapse structures, glial cell activation, vacuolar (spongiform) degeneration and ultimately neurodegeneration. Inhibiting the proliferation and pro-inflammatory responses of microglia via CSF1R inhibition decelerated CNS prion disease (Gómez-Nicola et al., 2013). Conversely, the partial depletion or deficiency in microglia was reported to enhance the accumulation of prions in the brain and accelerate the onset of clinical disease (Zhu et al., 2016, Carroll et al., 2018). However, 
none of these studies resulted in $100 \%$ microglial ablation nor addressed the potential confounding effects of ablative cell death or bystander effects, such as impact upon other non-microglial CSF1R-sensitive mononuclear phagocyte populations. For example although the CSF1R-targeting kinase inhibitor PLX5622 has been widely used to ablate the microglia in the brain, such kinase inhibitors also impact peripheral CSF1R-dependent macrophages (Hume and MacDonald, 2012). Since the ablation of peripheral macrophages enhances prion accumulation in the secondary lymphoid tissues (Beringue et al., 2000, Maignien et al., 2005), effects on peripheral macrophage populations in the above studies also cannot be excluded.

To address the above concerns we investigated CNS prion disease in CSf1 $r^{\triangle \mathrm{FIRE}}$ mice which have a complete and specific lack of microglia in the brain but retain brain-associated macrophages (Rojo et al., 2019). We show that microglial-deficiency in Csf1r $\triangle$ FIRE mice was associated with accelerated prion disease in the absence of increased $\operatorname{PrP}^{\mathrm{Sc}}$ accumulation or prion-seeding activity. Instead, earlier astrocyte activation was associated with increased synaptic engulfment and unfolded protein responses without induction of genes associated with neurotoxic (A1) or neuroprotective (A2) reactive astrocyte polarization (Liddelow et al., 2017). These data indicate that microglia provide neuroprotection during CNS prion disease independently of PrPSc clearance, and restrict the harmful effects of reactive astrocyte activation. Identification of the mechanisms by which the microglia provide neuroprotection during CNS prion disease may reveal novel targets for therapeutic intervention in these and other neurodegenerative disorders. 


\section{Results}

Microglia-deficient Csf1 ${ }^{\Delta \mathrm{FIRE}}$ mice rapidly succumb to prion disease

To determine the role of microglia in prion disease, groups of homozygous microglia-deficient

Csf1 $r^{\triangle \mathrm{FIRE}}$ transgenic mice and wild-type $\left(C s f 1 r^{\mathrm{WT}}\right)$ littermate controls were injected intracerebrally (IC) with the ME7 strain of mouse adapted scrapie prions. As expected, all the Csf1 ${ }^{\mathrm{WT}}$ mice displayed clinical signs of prion disease from approximately 140 days after injection and succumbed to terminal disease with a mean survival time of $167 \pm 5$ days. In CSf1 $r^{\Delta F I R E}$ mice, clinical manifestations of prion disease were evident by 98 days after infection and progressed rapidly resulting in a mean survival time of $124 \pm 2$ days (Figure 1A).

Longitudinal gait analysis during prion infection.

CNS prion disease in mice is associated with profound motor-coordination disturbances (Heitzman and Corp, 1968). Since microglia are proposed to be involved in the development of the cerebellum and motor function (Kana et al., 2019), we used longitudinal gait analysis to determine whether microglia-deficiency affected the onset of motor disturbances during CNS prion disease (Figure 1B-D). Contrary to the published study, our analyses revealed no significant impact of the complete absence of microglia in the cerebellum of $C s f 1 r^{\triangle F I R E}$ mice on motor function analyzed at any time point in the absence of the prion challenge.

As expected, various motor functions were rapidly impacted in prion disease. The base of stance (BOS, or distance between the hind paws) increased gradually with age in uninfected mice regardless of genotype (Figure 1B) but diverged by 10 days post infection (dpi) with prions and was maintained until $63 \mathrm{dpi}$ (9 weeks) in Csf1r ${ }^{\triangle F I R E}$ mice and $108 \mathrm{dpi}$ (15 weeks) in 
Csf1 ${ }^{\mathrm{WT}}$ mice. At the onset of clinical signs of prion disease at $101 \mathrm{dpi}$ (14 weeks, red pointed arrow) Csf1 $r^{\triangle \mathrm{FIRE}}$ mice were hyperactive and continued to perform Catwalk Gait analysis with ease until the terminal stage (red flat-head arrow). In contrast, Csf1r ${ }^{\mathrm{WT}}$ mice at the onset of clinical symptoms at $143 \mathrm{dpi}$ (20 weeks) (black pointed arrow) were severely ataxic and unable to cross the Catwalk within the time-period required for data acquisition.

Due to the potential effects of IC injection of prions into the right hemisphere on the contralateral paws, we analyzed the effects on footfall using only the unilateral right front and hind paws. A significant increase in hind paw area was observed at $10 \mathrm{dpi}$ in Csf1 $1 \mathrm{r}^{\mathrm{FIRE}}$ mice with a further large increase at $38 \mathrm{dpi}$. In contrast $C s f 1 r^{\mathrm{WT}}$ mice did not experience a large increase in right hind paw area until $129 \mathrm{dpi}, 3$ weeks before commencement of clinical 110 signs, these data are indicative of a more rapid response to prion infection in CSf1r ${ }^{\Delta F I R E}$ mice (Figure 1C). Concurrent with these changes in footprint area, footfall intensity was increased in the prion-infected mice (Figure 1D). Front footfall intensity increased significantly from 3 dpi in Csf1r ${ }^{\text {WT }}$ mice and this increase was maintained almost throughout the duration of the prion infection until the terminal stage. In contrast, footfall intensity in the prion-infected CSf $1 r^{\Delta F I R E}$ mice commenced at $10 \mathrm{dpi}$ and was maintained until onset of clinical symptoms at $101 \mathrm{dpi}$ (Figure 1D).

Complete absence of microgliosis in prion-infected Csf1r ${ }^{\triangle \mathrm{FIRE}}$ mice.

The brains of terminally-affected Csf1r ${ }^{\mathrm{WT}}$ mice displayed abundant, activated 120 microglia (allograft inhibitory factor-1-positive [AIF1+] cells), whereas these cells and other potential $\mathrm{AlF}^{+}$CNS-infiltrating mononuclear phagocyte populations remained absent in uninfected and terminally-affected $C s f 1 r^{\triangle F I R E}$ mice (Figure 2A\&B)(Rojo et al., 2019). RT-qPCR 
analysis confirmed that Aif1 (Figure 2C) and Csf1r (Figure 2D) mRNA expression was significantly increased in the brains of terminally-affected Csf1r ${ }^{\mathrm{WT}}$ mice when compared to uninfected controls, but remained almost undetectable in the brains of $\operatorname{Csf} 1 r^{\triangle F I R E}$ mice even at the terminal stage of prion disease. Expression of other important microglia genes including Itgam (Figure 2E), CX3cr1 (Figure 2F) and Tmem119 (Figure 2G) were also significantly increased in Csf1r $r^{\mathrm{WT}}$ mice, but absent in $C s f 1 r^{\triangle \mathrm{FIRE}}$ mice at the terminal stage of prion infection. The monocyte chemokine receptor Ccr2 (Figure 2H) was significantly increased following prion infection in $C s f 1 r^{\mathrm{WT}}$ mice, but not in $C s f 1 r^{\Delta \mathrm{FIRE}}$ mice. Together, these data show that onset of CNS prion disease was accelerated in $\operatorname{Csf} 1 r^{\triangle \mathrm{FIRE}}$ mice in the complete absence of microglia. Notably, the Csf1r $r^{\Delta F I R E}$ mice are not monocyte-deficient but their monocytes lack CSF1R expression (Rojo et al, 2019). The IHC and expression profiling indicates that the CSf1r $r^{\triangle F I R E}$ mutation also prevents monocyte recruitment into the injured brain.

Unaltered neuronal loss but reduced prion accumulation in the brains of microglia-deficient mice at the terminal stage.

Assessment of hippocampal CA1 pyramidal cells in hematoxylin and eosin stained brain sections (Figure $3 \mathbf{A}$ ) revealed no difference in neuronal density or the frequency of pyknotic 140 (apoptotic) neuronal nuclei between terminal prion-infected $C s f 1 r^{\mathrm{WT}}$ and $C s f 1 r^{\Delta \mathrm{FIRE}}$ mice despite the difference in time of onset of pathology (Figure 3B). The prion-specific vacuolation was also comparable in most brain areas of $C s f 1 r^{\mathrm{WT}}$ and $C s f 1 r^{\triangle F I R E}$ terminal prioninfected mice, except for a significant reduction of vacuolation in the cerebellar cortex (G2), inferior and middle cerebellar peduncles (W1) and decussation of superior cerebellar peduncles (W2) of brains from prion-infected Csf1 $r^{\Delta \text { FIRE }}$ mice (Figure 3C). This suggested the 
pathological impact of prion-infection upon the cerebellum was reduced in the Csf1 $r^{\Delta \mathrm{FIRE}}$ mice at the terminal stage of prion disease.

The relative expression level of $\operatorname{PrP}^{C}$ can directly influence prion disease duration (Manson et al., 1994, Fischer et al., 1996, Weissmann and Flechsig, 2003). Previous expression profiling of the cortex of $C s f 1 r^{\triangle F I R E}$ compared $C s f 1 r^{\mathrm{WT}}$ mice revealed no impacts on expression of Prnp mRNA (which encodes PrPC) or any other neuron-associated transcripts (Rojo et al., 2019). Expression of Prnp mRNA in the hippocampus in published mRNA microarray data GEO dataset GSE108207 (Rojo et al., 2019) (Figure 3D) and whole brain PrPC protein (Figure 3E) was similar between naïve $C s f 1 r^{\triangle \mathrm{FIRE}}$ mice and $C s f 1 r^{\mathrm{WT}}$ mice. Partial-deficiency or temporary ablation of microglia during CNS prion infection was reported to accelerate the accumulation of prion-disease-specific PrPSc in the brain (Zhu et al., 2016, Carroll et al., 2018). By contrast, PrPSc accumulation was reduced in the brains of $C S f 1 r^{\triangle F I R E}$ compared to $C s f 1 r^{\mathrm{WT}}$ mice with terminal pathology (Figure 3F).

160 Altered neuropathology in the absence of microglia during CNS prion disease.

Consistent with data presented in Figure 3F, immunostaining for prion disease-associated PrP $\left(\operatorname{PrP}^{d}\right)$ in the brains of $\operatorname{Csf} 1 r^{\Delta \mathrm{FIRE}}$ mice at the terminal stage was approximately $50 \%$ of the intensity detected in $\mathrm{Cs} f 1 \mathrm{r}^{\mathrm{WT}}$ mice (Figure 4A). Since the accumulation of $\mathrm{Pr}^{\mathrm{Sc}}$ within the brain increases as the infection proceeds (Tatzelt et al., 1999), this finding is most likely a consequence of their significantly shortened survival times and implies that microglia deficiency produces hyper-sensitivity to the accumulation of $\operatorname{PrPSc}$.

CNS prion disease is accompanied by extensive reactive astrocytosis characterized by high levels of expression of glial fibrillary acidic protein, CD44 and the CD44v6 alternative 
splice variant (Bradford et al., 2019). Microglia and microglial-derived factors have been shown to induce reactive astrocytosis in a range of neurodegenerative conditions (Liddelow et al., 2017, Kunyu Li, 2019, Vainchtein and Molofsky, 2020). Despite the absence of microglia, reactive astrocytes expressing high levels of GFAP (Figure 4B) and CD44 (Figure 4C) were increased in the brains of prion-infected $C s f 1 r^{\triangle F I R E}$ mice but the level of $\mathrm{GFAP}^{+}$and $\mathrm{CD}_{4} 4^{+}$ immunostaining was lower than in infected $C s f 1 r^{\mathrm{WT}}$ mice. As astrocyte activation also increases temporally during CNS prion infection (Hwang et al., 2009, Bradford et al., 2019), this again is most likely a consequence of the $C s f 1 r^{\Delta \mathrm{FIRE}}$ mice succumbing to terminal prion disease significantly earlier than infected $C s f 1 r^{\mathrm{WT}}$ mice. In summary, these data reveal that although CNS prion disease duration is shorter in microglia-deficient $C s f 1 r^{\triangle \mathrm{FIRE}}$ mice, this is not accompanied by increased neuronal vacuolation, prion accumulation or reactive astrocytosis at the terminal stage.

Absence of induction of neurotoxic 'A1' or neuroprotective 'A2' reactive astrocyte-associated genes in the brains of prion-infected microglia-deficient mice.

Reactive astrocytes may be classified into distinct functional subclasses; an A1 subclass with neurotoxic activity and A2 astrocytes considered neurotrophic (Liddelow et al., 2017). Microglia-derived factors have been implicated in the induction of pan- and A1-reactive astrocyte-associated genes (Liddelow et al., 2017). Consistent with the immunohistochemistry data presented in Figure 4, high levels of mRNA encoding the panreactive astrocyte-associated genes Gfap (Figure 5A), Cd44 (Figure 5B) and Cd44v6 (Figure 190 5C) were detected in the brains of prion-infected Csf1 ${ }^{\mathrm{WT}}$ mice. LPS-mediated induction of expression of pan-reactive astrocyte-associated genes including Gfap and Cd44 was reported 
to be blocked in microglia-deficient Csf1r-l- mice (Liddelow et al., 2017). However, because of the limited viability of Csf1r/- mice, these studies were performed at postnatal day 8 , and these mice are also deficient in peripheral macrophage populations. In the $C s f 1 r^{\Delta \mathrm{FIRE}}$ mice, the expression of Gfap, $C d 44$ and $C d 44 v 6$ was upregulated in response to prion infection despite the complete absence of microglia. These data demonstrate CNS prion-induced astrocyte activation is not dependent on the presence of microglia.

At the terminal stage of prion disease, the reactive astrocytes display a mixed $\mathrm{A} 1$ and A2 transcriptomic signature (Hartmann et al., 2019, Donaldson et al., 2020). The expression of the neurotoxic A1 astrocyte-associated genes Gbp2, Psmb8 and Srgn was upregulated in the brains of terminal prion-infected $C s f 1 r^{\mathrm{WT}}$ mice, but absent in $C s f 1 r^{\triangle \mathrm{FIRE}}$ mice (Figure 5D5F). Microglia-derived cytokines including tumor necrosis factor (TNF) are important inducers of neurotoxic A1 reactive astrocyte activation. Indeed, Tnf was elevated in the brains of prioninfected $C s f 1 r^{\mathrm{WT}}$ mice but absent in $C s f 1 r^{\triangle \mathrm{FIRE}}$ mice, coincident with the lack of induction of $A 1$ reactive astrocyte-associated gene expression. Consistent with previous data from the brains of mice infected with ME7 scrapie prions (Donaldson et al., 2020), neuroprotective A2 astrocyte-associated genes (B3gnt5, Ptx3) were not induced in the brains of infected Csf1 $r^{\mathrm{WT}}$ or Csf1 $r^{\triangle F I R E}$ mice (Figure $5 \mathrm{H}, \mathrm{I}$ ). Together these data show that CNS prion disease in microgliadeficient $\operatorname{Csf1} r^{\triangle \mathrm{FIRE}}$ mice is accompanied by reactive astrocytosis, but lacks evidence of a neurotoxic $\mathrm{A} 1$ or neuroprotective $\mathrm{A} 2$ profile. 
Accelerated onset of neuronal vacuolation but unaltered kinetics of prion accumulation in the brain in the complete absence of microglia.

To determine how disease progression was affected by the absence of microglia, brains were collected from groups of $C s f 1 r^{\mathrm{WT}}$ and $C s f 1 r^{\Delta \mathrm{FIRE}}$ mice at $98 \mathrm{dpi}$ prior to overt pathology. Prion-specific vacuolation was already more severe in prion-infected Csf1 ${ }^{\Delta \mathrm{FIRE}}$ mice in multiple brain regions (Figure 6A \& 6B) even though the levels of $\mathrm{Pr}^{\mathrm{Sc}}$ in the brains of $C s f 1 r^{\triangle F I R E}$ or Csf1r ${ }^{\mathrm{WT}}$ mice at $98 \mathrm{dpi}$ were indistinguishable (Figure 6C \& 6D). In parallel, the highly sensitive real-time quaking-induced conversion (RT-QulC) assay was used to quantify 220 the relative prion seeding activity present within the brains of each group (Atarashi et al., 2011). Consistent with data presented in Figure 6C, the relative levels of prion seeding activity were also similar in the brains of infected $C s f 1 r^{\triangle \mathrm{FIRE}}$ mice and $C S f 1 r^{\mathrm{WT}}$ mice (Figure 6E).

After IC injection, some of the infectious prions from the inoculum spread to the spleen via the bloodstream where they accumulate in stromal follicular dendritic cells (FDC) (Brown et al., 1999). Following accumulation within the spleen and other secondary lymphoid organs, the prions can subsequently spread back to the brain (Brown et al., 2012, Brown and Mabbott, 2014). In the absence of peripheral macrophages, the accumulation of prions in secondary lymphoid tissues is enhanced (Beringue et al., 2000, Maignien et al., 2005). Since certain peripheral macrophages will also have been ablated in the previous studies (Zhu et al., 2016, Carroll et al., 2018, Lei et al., 2020) it is plausible that this may have increased the burden of prions in the spleen and other secondary lymphoid organs, and by doing so, enhanced their rate of spread to the brain. However, such an effect was unlikely to responsible for the accelerated prion disease in $\operatorname{Csf1} r^{\triangle F I R E}$ mice, as a similar abundance of prion-specific PrPd was detected on FDC in the spleens of Csf1r $r^{\Delta \mathrm{FIRE}}$ mice and Csf1r $r^{\mathrm{WT}}$ mice 
(Figure 6F). This is consistent with the demonstration that spleen macrophage populations are not affected in Csf1r ${ }^{\triangle F I R E}$ mice (Rojo et al., 2019).

Accelerated onset of reactive astrocyte activation in the complete absence of microglia.

The increased pathology in multiple brain regions by 98 dpi (Figure 6A\&B) was 240 associated with profound astrocytosis in the Csf1 $r^{\triangle F I R E}$ mice. Figure 7A, B \& C shows increased $\mathrm{GFAP}^{+} \& \mathrm{CD}_{4} 4^{+}$morphologically reactive astrocytes the intermediate grey layer (motor associated area) of the superior colliculus (G3) of infected $C s f 1 r^{\Delta F I R E} C s f 1 r^{\mathrm{WT}}$ mice. This pattern was consistent with increased Gfap mRNA expression throughout the brain (Figure 7D) but Cd44 and Cd44v6 appeared unchanged (Figure 7E\&F). Astrocytes in the steady state prune synapses to help maintain neural circuitry (Chung et al., 2013). Abnormal astrocyte synaptic pruning has been implicated in the pathogenesis of some neurodegenerative disorders (reviewed in (Lee and Chung, 2019)), and synaptic alterations are considered to contribute to the early behavioral changes observed in during CNS prion disease (Cunningham et al., 2003). The astrocytosis seen at $98 \mathrm{dpi} C s f 1 r^{\triangle F I R E}$ mice was associated with puncta of staining for the synaptic protein PSD95 (Figure 7A). Figure 7G quantifies the presumptive increase in pruned synapses in the microglia-deficient mice compared to WT. This suggests that the reactive astrocytes in the brains of prion-infected $C s f 1 r^{\triangle F I R E}$ mice displayed signs of enhanced pruning of neuronal synapses.

Accelerated onset of unfolded protein response in the complete absence of microglia.

Accumulation of misfolded $\mathrm{PrP}^{\mathrm{Sc}}$ in the brain triggers the unfolded protein response in reactive astrocytes (Smith et al., 2020). Specifically, phosphorylation of protein kinase-like 
endoplasmic reticulum kinase (PERK) causes the transient shutdown of protein synthesis via phosphorylation of eukaryotic translation initiation factor $2 \mathrm{~A}(\mathrm{elF} 2 \alpha)$. Inhibition of PERKelF2 $\alpha$ signaling in astrocytes alleviated prion-induced neurodegeneration (Smith et al., 2020). Here, the levels of phosphorylated PERK (PERK-P) and phosphorylated elF2 $\alpha$ (elF2 $\alpha-P)$ were significantly increased in the brains of infected Csf1 $\triangle r^{\triangle F I R E}$ mice at 98 dpi when compared to infected Csf1r ${ }^{\mathrm{WT}}$ mice (Figure 8A-C). Immunohistochemical analysis also revealed PERK-P expression in $\mathrm{GFAP}^{+}$reactive astrocytes and neurons in infected $C s f 1 r^{\triangle \mathrm{FIRE}}$ mice (Figure 8D). However, by the terminal stage of prion infection similar levels of elF $2 \alpha-P$ were detected in the brains of each mouse group despite the $C s f 1 r^{\triangle F I R E}$ mice succumbing to clinical prion disease earlier (Figure $\mathbf{8 E} \mathbf{8} \mathbf{8 F}$ ). Thus, these data suggest that the earlier astrocyte activation and neuronal vacuolation in the prion-infected $C S f 1 r^{\triangle F I R E}$ mice was accompanied by an increased unfolded protein response.

\section{Discussion}

In this study we investigated prion neuropathogenesis in microglia-deficient Csf1r ${ }^{\triangle \mathrm{AIRE}}$ mice. Spongiform vacuolation and neuronal loss at the terminal stage were indistinguishable in $C S f 1 r^{\mathrm{WT}}$ and $C S f 1 r^{\triangle \mathrm{FIRE}}$ mice and the onset of pathology was not correlated with the accumulation of misfolded prions, which are in any case not directly neurotoxic (Benilova et al., 2020). Microglia deficiency did not lead to the increased accumulation of prions in the brain, suggesting that microglial degradation of prions (if it occurs) can be compensated by other cells such as reactive astrocytes. We conclude that the non-redundant function of microglia is to moderate the harmful effects of reactive astrocytes and/or to provide supportive factors to neurons (Sariol et al., 2020). Consistent with that interpretation, 
microglia can suppress astrocyte phagocytic activity and astrocytes are capable of complete, though slower, clearance of neurons in the absence of microglia (Damisah et al., 2020). Previous studies have used a CSF1R kinase inhibitor to infer the role of microglia in CNS prion disease and reported that overall expression of A1- and A2- reactive astrocyte-associated transcripts in the brain was enhanced upon microglial depletion (Carroll et al., 2018, Carroll et al., 2020). However, use of CSF1R inhibitor can lead to partial depletion of microglia, impact other kinases (e.g. KIT, FLT3), cause localized microglial cell death and likely impact monocytes and macrophages outside the brain. So, the impacts on pathology should be interpreted with caution (Hume et al., 2020). in the brains of $C s f 1 r^{\Delta F I R E}$ mice. Although there was no induction of A1 neurotoxic astrocyteassociated genes, the reactive astrocytes displayed signs of enhanced pruning of neuronal synapses. The observation of activated astrocytes engulfing synapses in the superior colliculus (G3) region of the brains of $\operatorname{CSf} 1 r^{\triangle F I R E}$ mice at $98 \mathrm{dpi}$ with prions was coincident with the commencement of overt clinical signs in these mice at this time. These observations strengthen the hypothesis that loss of neuronal connectivity underlies neurological symptoms and precedes complete loss of neurons (Jeffrey et al., 2000, Brown et al., 2001, Cunningham et al., 2003). The engulfment of damaged synapses and neurons by reactive astrocytes could provide a clearance mechanism to protect surrounding undamaged neurons and synapses, as neuronal damage is required for astrocyte-mediated toxicity (Guttenplan et al., 2020).

The reactive astrocytes in the brains of infected $C s f 1 r^{\triangle F I R E}$ mice also displayed increased phosphorylated activation of PERK and elF2 $\alpha$ in the unfolded protein response pathway. Targeted blockade of this pathway specifically in astrocytes has proved beneficial 
during prion disease (Smith et al., 2020). Our data from microglia-deficient Csf1 $r^{\Delta \mathrm{FIRE}}$ mice indicate that the microglia employ mechanisms to protect the neurons in the brain against prion infection by restricting both phagocytosis and unfolded protein response in astrocytes. A similar role for microglia has recently been described in the suppression of ATP-mediated excitoxicity in neurons (Badimon et al., 2020).

In conclusion, our data indicate that the microglia provide neuroprotection 310 independently of $\mathrm{PrP}^{\mathrm{Sc}}$ clearance during prion disease and inhibit neurotoxic reactive astrocyte activation. Since astrocytes can contribute to both prion replication (Raeber et al., 1997, Krejciova et al., 2017) and synaptic loss in infected brains, preventing these activities would have therapeutic potential (Smith et al., 2020). The previous characterization of the CSf1 ${ }^{\triangle \mathrm{AIRE}}$ mice included mRNA expression profiling of the hippocampus which identified 85 transcripts that were significantly depleted when compare to wild-type mice, and were presumably not compensated by astrocytes or other cells (Rojo et al., 2019). That list does not include most endosomal and lysosome-associated genes that are more highly expressed by microglia and by inference must be upregulated by other cells in $C s f 1 r^{\Delta \mathrm{FIRE}}$ mice. An overlapping gene list was generated by expression profiling multiple brain regions in the Csf1rko rat (Pridans et al., 2018). Amongst the most down-regulated transcripts are the three subunits of C1q, which have been implicated in regulating astrocyte function (Liddelow et al., 2017, Clarke et al., 2018) and neurodegeneration (Cho, 2019) and have complex roles in neuronal development and homeostasis (Vukojicic et al., 2019). These Csf1r-dependent genes provide a short list of non-redundant pathways that may be used by microglia to provide this neuroprotection and restrict the reactive astrocyte activation in prion disease. Paradoxically, given the focus of the literature on harmful functions of microglia, enhancing their functions 
bioRxiv preprint doi: https://doi.org/10.1101/2021.01.05.425436; this version posted January 6,2021 . The copyright holder for this preprint

(which was not certified by peer review) is the author/funder, who has granted bioRxiv a license to display the preprint in perpetuity. It is made available under aCC-BY-NC-ND 4.0 International license.

may provide novel intervention treatments against these devastating neurodegenerative disorders. 


\section{Methods}

Ethics statement

Ethical approvals for the in vivo mouse experiments were obtained from The Roslin Institute's and University of Edinburgh's ethics committees. These experiments were also performed under the authority of UK Home Office Project Licence (PA75389E7) in accordance within the guidelines and regulations of the UK Home Office 'Animals (scientific procedures) Act 1986'. Appropriate care was provided to minimise harm and suffering, and anaesthesia was administered where necessary. Mice were humanely culled at the end of the experiments by cervical dislocation.

Mice

CSf1 $r^{\triangle F I R E / W T}$ mice produced in-house (Rojo et al., 2019) were crossed to produce homozygous

$340 C s f 1 r^{\triangle \mathrm{FIRE}}\left(C s f 1 r^{\mathrm{AFIRE} / \mathrm{AFIRE}}\right)$ or $\operatorname{Cs} f 1 r^{\mathrm{WT}}\left(\mathrm{Cs} f 1 r^{\mathrm{WT} / \mathrm{WT}}\right)$ littermates. Offspring were genotyped as described (Rojo et al., 2019). Pups were weaned and co-housed under specific pathogen-free conditions with a $12: 12$-hr light : dark cycle, food, and water were provided ad libitum.

Prion infection

Mice were infected at 10 weeks old via intracerebral injection with $20 \mu \mathrm{l}$ of a $0.01 \%$ (weight/volume) brain homogenate prepared from mice terminally infected with ME7 scrapie prions. Mice were culled at the intervals indicated after exposure, or observed for signs of clinical prion disease as described elsewhere (Brown and Mabbott, 2014) and culled at a standard clinical end-point. Disease incubation periods were calculated as the interval between injection and positive clinical assessment of terminal prion disease. 
Gait analysis was performed weekly using the CatWalkXT (Noldus) from 8 weeks of age until positive clinical assessment of prion disease. Uninfected mice of both genotype were monitored weekly from 8 to 30 weeks of age as controls.

Neuropathological analysis

Clinical prion disease diagnosis was confirmed by histopathological assessment of vacuolation (spongiform pathology) in the brain. Coronal sections of paraffin-embedded brain tissue were cut at $6 \mu \mathrm{m}$ thickness, de-paraffinized and stained with haematoxylin \& eosin and scored for spongiform vacuolar degeneration as described previously (Fraser and Dickinson, 1967). For the construction of lesion profiles, sections were scored for the presence and severity (scale 0-5) of prion-disease-specific vacuolation in nine grey matter and three white matter areas: G1, dorsal medulla; G2, cerebellar cortex; G3, superior colliculus; G4, hypothalamus; G5, thalamus; G6, hippocampus; G7, septum; G8, retrosplenial and adjacent motor cortex; G9, cingulate and adjacent motor cortex; W1, inferior and middle cerebellar peduncles; W2, decussation of superior cerebellar peduncles; and W3, cerebellar peduncles.

Immunohistochemistry

Paraffin-embedded sections (thickness $6 \mu \mathrm{m}$ ) were deparaffinized, pre-treated by autoclaving in distilled water at $121^{\circ} \mathrm{C}$ for $15 \mathrm{~min}$, and for PrP-immunostaining immersed in $98 \%$ formic acid for $10 \mathrm{~min}$, endogenous peroxidases were quenched by immersion in $4 \% \mathrm{H}_{2} \mathrm{O}_{2}$ in methanol for $5 \mathrm{~min}$. Sections were incubated overnight with primary antibodies (see Table 1). Primary antibody binding was detected using biotinylated goat anti-species specific antibodies (Jackson Immunoresearch, West Grove, PA) where necessary and visualized using the Elite $A B C / H R P$ kit (Vector Laboratories, Peterborough, UK) and diaminobenzidine (DAB) 
between stringent washing steps. Sections were lightly counterstained with haematoxylin and imaged on a Nikon Ni.1 Brightfield Compound upright microscope, 4x/10x/20x/ air lenses, Zeiss 105 c colour camera \& Zen 2 software for image capture. For fluorescence immunohistochemistry primary antibodies were detected with species-specific Alexa-Fluor 488 or 594 conjugated secondary antibodies. Perk-P staining was detected using biotinylated goat anti-rabbit specific antibodies (Jackson Immunoresearch, West Grove, PA) and visualized using the Elite $\mathrm{ABC} / \mathrm{HRP}$ kit (Vector Laboratories, Peterborough, UK) and Tyramide AlexaFluor488 (Biotium) and imaged on a Zeiss LSM 710 Confocal Microscope with 6 Laser Lines (405/458/488/514/543/633nm)/ 2 PMT's + 32 channel Quasar detector. 10x/20x/40x1.3na oil/60x1.4na oil lenses using Zen Software.

\section{Western blot analysis}

Brain homogenates (10\% weight/volume) were prepared in NP40 lysis buffer (1\% NP40, 0.5\% sodium deoxycholate, $150 \mathrm{mM} \mathrm{NaCl}, 50 \mathrm{mM}$ TrisHCl [pH 7.5]). For the detection of $\operatorname{PrP}^{\mathrm{Sc}}$ a sample of homogenate was incubated at $37^{\circ} \mathrm{C}$ for $1 \mathrm{~h}$ with $20 \mu \mathrm{g} / \mathrm{ml}$ proteinase $\mathrm{K}$ (PK) and digestion halted by addition of $1 \mathrm{mM}$ phenylmethylsulfonyl fluoride. Samples were denatured at $98^{\circ} \mathrm{C}$ for $15 \mathrm{~min}$ in $1 \mathrm{x}$ SDS sample buffer (Life Technologies) and separated via electrophoresis through $12 \%$ Tris-glycine polyacrylamide gels (Nupage, Life Technologies) and transferred to polyvinylidene difluoride PVDF membranes by semi-dry electroblotting. Primary antibodies (see Table 1) were detected by horseradish peroxidase-conjugated goat anti-species specific antibody (Jackson Immunoresearch) and visualised via chemiluminescence (BM Chemiluminescent substrate kit, Roche, Burgess Hill, UK) as described previously (Bradford et al., 2017). 
Table 1: Primary antibodies

\begin{tabular}{|l|l|l|}
\hline Target & Antibody & Supplier / Reference \\
\hline ß-Actin & Mouse monoclonal C4 & Santa Cruz Biotechnology \\
\hline CD44 & $\begin{array}{l}\text { Biotinylated rat anti-mouse/human } \\
\text { monoclonal IM7 }\end{array}$ & Biolegend \\
\hline Iba1 & Rabbit polyclonal & Wako \\
\hline GFAP & Rabbit anti bovine polyclonal & Dako \\
\hline Phopsho-Eif2a (Ser51) & Rabbit monoclonal 119A11 & Cell Signaling Technology \\
\hline Phospho-PERK (Thr980) & Rabbit monoclonal 16F8 & Cell Signaling Technology \\
\hline PrP & Mouse monoclonal BH1 & (McCutcheon et al., 2014) \\
\hline PSD95 & Mouse monoclonal K28/43 & Biolegend \\
\hline
\end{tabular}

Image analyses

Image analysis were performed using ImageJ software (http://imagej/nih.gov/ii) (Schneider et al., 2012). The magnitude of PrPd , GFAP and CD44 immunostaining on DAB stained sections was compared as previously described (Bradford et al., 2019). Briefly, the optical density (OD) values for immunostaining were calculated using ImageJ software following H-DAB deconvolution. Mean grey OD values were measured from DAB grayscale images (scaled 0255) and expressed as a \% relative intensity by dividing by the maximum value (255). Immunofluorescent images were analysed using ImageJ as previously described (McCulloch et al., 2011). Briefly intensity thresholds were applied and then the number of pixels of each colour counted and presented as a proportion of the total pixel area under analysis (\% area coverage). The preferential co-localisation of fluorochromes were determined by comparison of the observed distribution of colors with those predicted by the null hypothesis that each element of positive staining was randomly and independently distributed. Values found to be significantly greater than the null hypothesis confirm significant co-localisation of fluorochromes. The assessment of relative synaptic pruning was calculated as the $\%$ of PSD95 staining co-localised with GFAP relative to total PSD95. Western blot images were subjected 
to densitometric analysed by ImageJ. Briefly lanes and bands were identified, threshold levels set and area under the curve measurements taken (pixels). For $\operatorname{PrP}^{\mathrm{C}}$ and $\operatorname{PrPSc}$ relative expression levels were calculated as a percentage relative to a control normal brain $\operatorname{PrPC}$ measurement.

Real-Time quaking induced conversion (RT-QuiC)

Brain homogenates were diluted at $10-3$ volume/volume in PBS. RT-QuIC reaction mix prepared as follows: $10 \mathrm{mM}$ phosphate buffer (pH 7.4), $170 \mathrm{mM} \mathrm{NaCl}$ (total $300 \mathrm{mM}$ including

420 phosphate buffer), $0.1 \mathrm{mg} / \mathrm{mL}$ recombinant PrPc (Bank Vole 23-230, (Orrú et al., 2015) construct kindly provided by Byron Caughey), $10 \mu \mathrm{M}$ Thioflavin-T (ThT), and $10 \mu \mathrm{M}$ ethylenediaminetetraacetic acid tetrasodium salt (EDTA). Reactions were performed in quadruplicate. Aliquots of the reaction mix $(98 \mu \mathrm{L})$ were loaded into each well of a black 96well plate with a clear bottom (Thermo Scientific) and seeded with $2 \mu \mathrm{L}$ of $\mathrm{BH}$ dilution. Samples were incubated in a FLUOstar ${ }^{\circledR}$ OMEGA plate reader (BMG LABTECH Ltd.) at $42^{\circ} \mathrm{C}$ for $80 \mathrm{~h}$ with intermittent shaking cycles: $1 \mathrm{~min}$ shake (double orbital, 700rpm), $1 \mathrm{~min}$ rest. Fluorescence measurements ( $450 \mathrm{~nm}$ excitation and $480 \mathrm{~nm}$ emission; bottom read), referred to as relative fluorescent units ( $\mathrm{rfu}$ ) were taken every $15 \mathrm{~min}$. A baseline rfu of $~ 38,000$ for unseeded and initial BH seeded reactions were recorded, with saturation occurring at 260,000 $430 \mathrm{rfu}$. All 4 quadruplicates of the 8 test samples, displayed a significant rise in rfu over time; a sample was considered "positive for PrP seeding" if replicates crossed a threshold of fluorescence set at 50,000 rfu based on the mean \pm 10SD (36941 \pm 8348$)$ of the unseeded negative control samples analysed. The mean time for each quadruplicate reading to reach the 50,000 rfu threshold was calculated and plotted. 
Gene expression analysis via quantitative RT-PCR

Total RNA was isolated from brain using RNABee (AMSBio, Abingdon, UK) and RNeasy Mini kit (Qiagen). RNA was Dnase treated (Promega) to remove genomic DNA. Reverse transcription of polyA mRNA from $5 \mu \mathrm{g}$ total DNA-free RNA was performed using Superscript First Strand Synthesis (Invitrogen) with Oligo-dT primers. Quantitative PCR (qPCR) were performed using SYBR master mix (Rox) (Roche) on an MX3005pro (Stratagene) using the primer sequences detailed (Table 2). Gene expression relative to naïve $C s f 1 r^{\mathrm{WT}}$ mice was calculated using the $\Delta \Delta C T$ method (Livak and Schmittgen, 2001) using $R p / 19$ as a reference gene.

Table 2: Oligonucleotide primers

\begin{tabular}{|l|l|l|}
\hline Gene & Forward primer & Reverse Primer \\
\hline Aif1 & GGATCAACAAGCAATTCCTCGA & CTGAGAAAGTCAGAGTAGCTGA \\
\hline B3gnt5 & CGTGGGGCAATGAGAACTAT & CCCAGCTGAACTGAAGAAGG \\
\hline Ccr2 & AGCACATGTGGTGAATCCAA & TGCCATCATAAAGGAGCCA \\
\hline Cd44 & ACCTTGGCCACCACTCCTAA & GCAGTAGGCTGAAGGGTTGT \\
\hline Cd44v6 & CTAATAGTACAGCAGAAGCAGCAGCTA & CCTGCCATCCGTTCTGAAA \\
\hline Csf1r & AGGCAGGCTGGAATAATCTGACCT & CGTCACAGAACAGGACATCAGAGC \\
\hline Cx3cr1 & CAGCATCGACCGGTACCTT & GCTGCACTGTCCGGTTGTT \\
\hline Gbp2 & GGGGTCACTGTCTGACCACT & GGGAAACCTGGGATGAGATT \\
\hline Gfap & AGAAAGGTTGAATCGCTGGA & CGGCGATAGTCGTTAGCTTC \\
\hline Itgam & TGGCCTATACAAGCTTGGCTTT & AAAGGCCGTTACTGAGGTGG \\
\hline Psmb8 & CAGTCCTGAAGAGGCCTACG & CACTTTCACCCAACCGTCTT \\
\hline Ptx3 & AACAAGCTCTGTTGCCCATT & TCCCAAATGGAACATTGGAT \\
\hline Srgn & GCAAGGTTATCCTGCTCGGA & TGGGAGGGCCGATGTTATTG \\
\hline Tmem119 & GTGTCTAACAGGCCCCAGAA & AGCCACGTGGTATCAAGGAG \\
\hline Tnfa & TGTGCTCAGAGCTTTCAACAA & CTTGATGGTGGTGCATGAGA \\
\hline Rpl19 & GAAGGTCAAAGGGAATGTGTCA & CCTTGTCTGCCTTCAGCTTGT \\
\hline
\end{tabular}




\section{Statistical analysis}

Statistical analysis was performed using GraphPad Prism 6.01 (GraphPad Software Inc.). Survival curve analysis performed using Log-rank [Mantel Cox] Test. Image and gene expressed as dot plots of individual animal observations with median values indicated (bar). CatWalkXT analysis performed using two-way ANOVA and expressed as group mean with 95\% confidence interval. Values of $P<0.05$ were accepted as significant.

\section{Acknowledgements}

We thank Darren Smith, Fraser Laing, Aileen Boyle, Bob Fleming, Graeme Robertson and the Biological and Veterinary Services, Bioimaging and Pathology Services groups (University of Edinburgh, UK) for helpful advice and technical support. We thank Giovanna Malucci and Ibrahim Humoud (University of Cambridge, UK) for assistance with immunostaining. This work was supported by funding from the RS Macdonald Charitable Trust, Edinburgh Neuroscience and project (BB/S005471/1) and Institute Strategic Programme Grant funding from the Biotechnology and Biological Sciences Research Council (grant numbers BBS/E/D/20002173 \& BBS/E/D/10002071).

\section{Author Contributions}

$\mathrm{BB}, \mathrm{DH}, \mathrm{CP}$ \& NM conceived the study; NM obtained funding; BB \& NM designed the experiments; BB \& LM performed the experiments and acquired data; all authors interpreted these data and contributed to the final version of this report. 


\section{References}

470 ATARASHI, R., SANO, K., SATOH, K. \& NISHIDA, N. 2011. Real-time quaking-induced conversion. Prion, 5(3), 150-153.

BADIMON, A., STRASBURGER, H. J., AYATA, P., CHEN, X., NAIR, A., IKEGAMI, A., HWANG, P., CHAN, A. T., GRAVES, S. M., UWERU, J. O., LEDDEROSE, C., KUTLU, M. G., WHEELER, M. A., KAHAN, A., ISHIKAWA, M., WANG, Y.-C., LOH, Y.-H. E., JIANG, J. X., SURMEIER, D. J., ROBSON, S. C., JUNGER, W. G., SEBRA, R., CALIPARI, E. S., KENNY, P. J., EYO, U. B., COLONNA, M., QUINTANA, F. J., WAKE, H., GRADINARU, V. \& SCHAEFER, A. 2020. Negative feedback control of neuronal activity by microglia. Nature.

BENILOVA, I., REILLY, M., TERRY, C., WENBORN, A., SCHMIDT, C., MARINHO, A. T., RISSE, E., AL-DOUJAILY, H., WIGGINS DE OLIVEIRA, M., SANDBERG, M. K., WADSWORTH, J. D. F., JAT, P. S. \& COLLINGE, J. 2020. Highly infectious prions are not directly neurotoxic. 117(38), 23815-23822.

BERINGUE, V., DEMOY, M., LASMEZAS, C. I., GOURITIN, B., WEINGARTEN, C., DESLYS, J. P., ANDREUX, J. P., COUVREUR, P. \& DORMONT, D. 2000. Role of spleen macrophages in the clearance of scrapie agent early in pathogenesis. J Pathol, 190(4), 495-502.

BRADFORD, B. M., REIZIS, B. \& MABBOTT, N. A. 2017. Oral Prion Disease Pathogenesis Is Impeded in the Specific Absence of CXCR5-Expressing Dendritic Cells. J Virol, 91(10), e00124-17.

BRADFORD, B. M., WIJAYA, C. A. W. \& MABBOTT, N. A. 2019. Discrimination of Prion Strain Targeting in the Central Nervous System via Reactive Astrocyte Heterogeneity in CD44 Expression. Frontiers in Cellular Neuroscience, 13(411.

BROWN, D., BELICHENKO, P., SALES, J., JEFFREY, M. \& FRASER, J. R. 2001. Early loss of dendritic spines in murine scrapie revealed by confocal analysis. Neuroreport, 12(1), 179-83.

BROWN, K. L., GOSSNER, A., MOK, S. \& MABBOTT, N. A. 2012. The effects of host age on the transport of complement-bound complexes to the spleen and the pathogenesis of intravenous scrapie infection. J Virol, 86(1), 25-35.

BROWN, K. L. \& MABBOTT, N. A. 2014. Evidence of subclinical prion disease in aged mice following exposure to bovine spongiform encephalopathy. J Gen Virol, 95(Pt 1), 23143.

BROWN, K. L., STEWART, K., RITCHIE, D., MABBOTT, N. A., WILLIAMS, A., FRASER, H., MORRISON, W. I. \& BRUCE, M. E. 1999. Scrapie replication in lymphoid tissues depends on PrP-expressing follicular dendritic cells. Nature Medicine, 5), 1308-1312.

CARROLL, J. A., RACE, B., WILLIAMS, K., STRIEBEL, J. \& CHESEBRO, B. 2018. Microglia Are Critical in Host Defense against Prion Disease. J Virol, 92(15), e00549-18.

CARROLL, J. A., RACE, B., WILLIAMS, K., STRIEBEL, J. \& CHESEBRO, B. 2020. RNA-seq and network analysis reveal unique glial gene expression signatures during prion infection. Molecular Brain, 13(1), 71.

$\mathrm{CHO}$, K. 2019. Emerging Roles of Complement Protein C1q in Neurodegeneration. Aging and disease, 10(3), 652-663.

CHUNG, W. S., CLARKE, L. E., WANG, G. X., STAFFORD, B. K., SHER, A., CHAKRABORTY, C., 510 JOUNG, J., FOO, L. C., THOMPSON, A., CHEN, C. F., SMITH, S. J. \& BARRES, B. A. 2013. Astrocytes mediate synapse elimination through MEGF10 and MERTK pathways. Nature, 504(7480), 394-+.

CLARKE, L. E., LIDDELOW, S. A., CHAKRABORTY, C., MÜNCH, A. E., HEIMAN, M. \& BARRES, B. A. 2018. Normal aging induces A1-like astrocyte reactivity. 115(8), E1896-E1905. 
CUNNINGHAM, C., DEACON, R., WELLS, H., BOCHE, D., WATERS, S., DINIZ, C. P., SCOTT, H., RAWLINS, J. N. \& PERRY, V. H. 2003. Synaptic changes characterize early behavioural signs in the ME7 model of murine prion disease. Eur J Neurosci, 17(10), 2147-55.

DAMISAH, E. C., HILL, R. A., RAI, A., CHEN, F., ROTHLIN, C. V., GHOSH, S. \& GRUTZENDLER, J. 2020. Astrocytes and microglia play orchestrated roles and respect phagocytic territories during neuronal corpse removal in vivo. 6(26), eaba3239.

DONALDSON, D. S., BRADFORD, B. M., ELSE, K. J. \& MABBOTT, N. A. 2020. Accelerated onset of CNS prion disease in mice co-infected with a gastrointestinal helminth pathogen during the preclinical phase. Scientific Reports, 10(1), 4554.

FISCHER, M., RULICKE, T., RAEBER, A., SAILER, A., MOSER, M., OESCH, B., BRANDNER, S., AGUZZI, A. \& WEISSMANN, C. 1996. Prion protein (PrP) with amino-proximal deletions restoring susceptibility of PrP knockout mice to scrapie. EMBO J, 15(6), 1255-64.

FRASER, H. \& DICKINSON, A. G. 1967. Distribution of experimentally induced scrapie lesions in the brain. Nature, 216(5122), 1310-1.

$530 \quad$ Proliferation during Chronic Neurodegeneration. 33(6), 2481-2493.

GUTTENPLAN, K. A., STAFFORD, B. K., EL-DANAF, R. N., ADLER, D. I., MÜNCH, A. E., WEIGEL, M. K., HUBERMAN, A. D. \& LIDDELOW, S. A. 2020. Neurotoxic Reactive Astrocytes Drive Neuronal Death after Retinal Injury. Cell Reports, 31(12), 107776.

HARTMANN, K., SEPULVEDA-FALLA, D., ROSE, I. V. L., MADORE, C., MUTH, C., MATSCHKE, J., BUTOVSKY, O., LIDDELOW, S., GLATZEL, M. \& KRASEMANN, S. 2019. Complement 3+astrocytes are highly abundant in prion diseases, but their abolishment led to an accelerated disease course and early dysregulation of microglia. Acta Neuropathologica Communications, 7(1), 83.

$540 \quad$ and scrapie mice. Res Vet Sci, 9(6), 600-1.

HUME, D. A., CARUSO, M., FERRARI-CESTARI, M., SUMMERS, K. M., PRIDANS, C. \& IRVINE, K. M. 2020. Phenotypic impacts of CSF1R deficiencies in humans and model organisms. 107(2), 205-219.

HUME, D. A. \& MACDONALD, K. P. A. 2012. Therapeutic applications of macrophage colonystimulating factor-1 (CSF-1) and antagonists of CSF-1 receptor (CSF-1R) signaling. Blood, 119(8), 1810-1820.

HWANG, D., LEE, I. Y., YOO, H., GEHLENBORG, N., CHO, J. H., PETRITIS, B., BAXTER, D., PITSTICK, R., YOUNG, R., SPICER, D., PRICE, N. D., HOHMANN, J. G., DEARMOND, S. J., CARLSON, G. A. \& HOOD, L. E. 2009. A systems approach to prion disease. Mol Syst

$550 \quad$ Biol, 5), 252.

JEFFREY, M., HALLIDAY, W. G., BELL, J., JOHNSTON, A. R., MACLEOD, N. K., INGHAM, C., SAYERS, A. R., BROWN, D. A. \& FRASER, J. R. 2000. Synapse loss associated with abnormal PrP precedes neuronal degeneration in the scrapie-infected murine hippocampus. Neuropathol Appl Neurobiol, 26(1), 41-54.

KANA, V., DESLAND, F. A., CASANOVA-ACEBES, M., AYATA, P., BADIMON, A., NABEL, E., YAMAMURO, K., SNEEBOER, M., TAN, I.-L., FLANIGAN, M. E., ROSE, S. A., CHANG, C., LEADER, A., LE BOURHIS, H., SWEET, E. S., TUNG, N., WROBLEWSKA, A., LAVIN, Y., SEE, P., BACCARINI, A., GINHOUX, F., CHITU, V., STANLEY, E. R., RUSSO, S. J., YUE, Z., BROWN, B. D., JOYNER, A. L., DE WITTE, L. D., MORISHITA, H., SCHAEFER, A. \& MERAD, M. 2019. CSF-1 controls cerebellar microglia and is required for motor function and social interaction. Journal of Experimental Medicine, 216(10), 2265-2281. 
KREJCIOVA, Z., ALIBHAI, J., ZHAO, C., KRENCIK, R., RZECHORZEK, N. M., ULLIAN, E. M., MANSON, J., IRONSIDE, J. W., HEAD, M. W. \& CHANDRAN, S. 2017. Human stem cellderived astrocytes replicate human prions in a PRNP genotype-dependent manner. $J$ Exp Med, 214(12), 3481-3495.

KUNYU LI, J. L., JIALIN ZHENG, SONG QIN 2019. Reactive Astrocytes in Neurodegenerative Diseases. 10(3), 664-675.

LEE, E. \& CHUNG, W.-S. 2019. Glial Control of Synapse Number in Healthy and Diseased Brain. Frontiers in cellular neuroscience, 13), 42-42.

570 LEI, F., CUI, N., ZHOU, C., CHODOSH, J., VAVVAS, D. G. \& PASCHALIS, E. I. 2020. CSF1R inhibition by a small-molecule inhibitor is not microglia specific; affecting hematopoiesis and the function of macrophages.), 201922788.

LIDDELOW, S. A., GUTTENPLAN, K. A., CLARKE, L. E., BENNETT, F. C., BOHLEN, C. J., SCHIRMER, L., BENNETT, M. L., MUNCH, A. E., CHUNG, W. S., PETERSON, T. C., WILTON, D. K., FROUIN, A., NAPIER, B. A., PANICKER, N., KUMAR, M., BUCKWALTER, M. S., ROWITCH, D. H., DAWSON, V. L., DAWSON, T. M., STEVENS, B. \& BARRES, B. A. 2017. Neurotoxic reactive astrocytes are induced by activated microglia. Nature, 541(7638), 481-487.

LIVAK, K. J. \& SCHMITTGEN, T. D. 2001. Analysis of Relative Gene Expression Data Using RealTime Quantitative PCR and the 2- $\triangle \triangle C T$ Method. Methods, 25(4), 402-408.

MAIGNIEN, T., SHAKWEH, M., CALVO, P., MARCE, D., SALES, N., FATTAL, E., DESLYS, J. P., COUVREUR, P. \& LASMEZAS, C. I. 2005. Role of gut macrophages in mice orally contaminated with scrapie or BSE. Int J Pharm, 298(2), 293-304.

MANSON, J. C., CLARKE, A. R., MCBRIDE, P. A., MCCONNELL, I. \& HOPE, J. 1994. Prp Gene Dosage Determines the Timing but Not the Final Intensity or Distribution of Lesions in Scrapie Pathology. Neurodegeneration, 3(4), 331-340.

MCCULLOCH, L., BROWN, K. L., BRADFORD, B. M., HOPKINS, J., BAILEY, M., RAJEWSKY, K., MANSON, J. C. \& MABBOTT, N. A. 2011. Follicular Dendritic Cell-Specific Prion Protein $(\mathrm{PrPC})$ Expression Alone Is Sufficient to Sustain Prion Infection in the Spleen. Plos Pathogens, 7(12), e1002402.

590 MCCUtChEON, S., LANGEVELD, J. P. M., TAN, B. C., GILL, A. C., DE WOLF, C., MARTIN, S., GONZALEZ, L., ALIBHAI, J., BLANCO, A. R. A., CAMPBELL, L., HUNTER, N. \& HOUSTON, E. F. 2014. Prion protein-specific antibodies that detect multiple TSE agents with high sensitivity. PloS one, 9(3), e91143-e91143.

NAKAYAMA, H., ABE, M., MORIMOTO, C., IIDA, T., OKABE, S., SAKIMURA, K. \& HASHIMOTO, K. 2018. Microglia permit climbing fiber elimination by promoting GABAergic inhibition in the developing cerebellum. Nature Communications, 9(1), 2830.

ORRÚ, C. D., GROVEMAN, B. R., RAYMOND, L. D., HUGHSON, A. G., NONNO, R., ZOU, W., GHETTI, B., GAMBETTI, P. \& CAUGHEY, B. 2015. Bank Vole Prion Protein As an Apparently Universal Substrate for RT-QulC-Based Detection and Discrimination of Prion Strains. PLOS Pathogens, 11(6), e1004983.

PRIDANS, C., RAPER, A., DAVIS, G. M., ALVES, J., SAUTER, K. A., LEFEVRE, L., REGAN, T., MEEK, S., SUTHERLAND, L., THOMSON, A. J., CLOHISEY, S., BUSH, S. J., ROJO, R., LISOWSKI, Z. M., WALLACE, R., GRABERT, K., UPTON, K. R., TSAI, Y. T., BROWN, D., SMITH, L. B., SUMMERS, K. M., MABBOTT, N. A., PICCARDO, P., CHEESEMAN, M. T., BURDON, T. \& HUME, D. A. 2018. Pleiotropic Impacts of Macrophage and Microglial Deficiency on Development in Rats with Targeted Mutation of the $<$ em $>$ Csf1 $r</ e m>$ Locus. 201(9), 2683-2699. 
PRINZ, M., JUNG, S. \& PRILLER, J. 2019. Microglia Biology: One Century of Evolving Concepts. Cell, 179(2), 292-311.

PRUSINER, S. B. 1982. Novel proteinaceous infectious particles cause scrapie. Science, 216(4542), 136-44.

RAEBER, A. J., RACE, R. E., BRANDNER, S., PRIOLA, S. A., SAILER, A., BESSEN, R. A., MUCKE, L., MANSON, J., AGUZZI, A., OLDSTONE, M. B., WEISSMANN, C. \& CHESEBRO, B. 1997. Astrocyte-specific expression of hamster prion protein (PrP) renders PrP knockout mice susceptible to hamster scrapie. EMBO J, 16(20), 6057-65.

RIO-HORTEGA 1919. El tercer elemento de los centros nerviosos. 9), 51.

ROJO, R., RAPER, A., OZDEMIR, D. D., LEFEVRE, L., GRABERT, K., WOLLSCHEID-LENGELING, E., BRADFORD, B., CARUSO, M., GAZOVA, I., SÁNCHEZ, A., LISOWSKI, Z. M., ALVES, J., MOLINA-GONZALEZ, I., DAVTYAN, H., LODGE, R. J., GLOVER, J. D., WALLACE, R., MUNRO, D. A. D., DAVID, E., AMIT, I., MIRON, V. E., PRILLER, J., JENKINS, S. J., HARDINGHAM, G. E., BLURTON-JONES, M., MABBOTT, N. A., SUMMERS, K. M., HOHENSTEIN, P., HUME, D. A. \& PRIDANS, C. 2019. Deletion of a Csf1r enhancer selectively impacts CSF1R expression and development of tissue macrophage populations. Nature Communications, 10(1), 3215.

SARIOL, A., MACKIN, S., ALLRED, M.-G., MA, C., ZHOU, Y., ZHANG, Q., ZOU, X., ABRAHANTE, J. E., MEYERHOLZ, D. K. \& PERLMAN, S. 2020. Microglia depletion exacerbates demyelination and impairs remyelination in a neurotropic coronavirus infection.), 202007814.

SCHNEIDER, C. A., RASBAND, W. S. \& ELICEIRI, K. W. 2012. NIH Image to ImageJ: 25 years of image analysis. Nature Methods, 9(7), 671-675.

SMITH, H. L., FREEMAN, O. J., BUTCHER, A. J., HOLMQVIST, S., HUMOUD, I., SCHATZL, T., HUGHES, D. T., VERITY, N. C., SWINDEN, D. P., HAYES, J., DE WEERD, L., ROWITCH, D. H., FRANKLIN, R. J. M. \& MALLUCCI, G. R. 2020. Astrocyte Unfolded Protein Response Induces a Specific Reactivity State that Causes Non-Cell-Autonomous Neuronal Degeneration. Neuron, 105(5), 855-866 e5.

TATZELT, J., GROTH, D. F., TORCHIA, M., PRUSINER, S. B. \& DEARMOND, S. J. 1999. Kinetics of prion protein accumulation in the CNS of mice with experimental scrapie. $J$ Neuropathol Exp Neurol, 58(12), 1244-9.

VAINCHTEIN, I. D. \& MOLOFSKY, A. V. 2020. Astrocytes and Microglia: In Sickness and in Health. Trends Neurosci, 43(3), 144-154.

VUKOJICIC, A., DELESTRÉE, N., FLETCHER, E. V., PAGIAZITIS, J. G., SANKARANARAYANAN, S., YEDNOCK, T. A., BARRES, B. A. \& MENTIS, G. Z. 2019. The Classical Complement Pathway Mediates Microglia-Dependent Remodeling of Spinal Motor Circuits during Development and in SMA. Cell reports, 29(10), 3087-3100.e7.

WEISSMANN, C. \& FLECHSIG, E. 2003. PrP knock-out and PrP transgenic mice in prion research. British Medical Bulletin, 66(1), 43-60.

ZHU, C., HERMANN, U. S., FALSIG, J., ABAKUMOVA, I., NUVOLONE, M., SCHWARZ, P., FRAUENKNECHT, K., RUSHING, E. J. \& AGUZZI, A. 2016. A neuroprotective role for microglia during prion diseaes. Journal of Experimental Medicine, 213), 1047-1059. 
Figure 1. Csf1r $r^{\Delta F I R E}$ mice rapidly succumb to prion disease (A) Survival curve following IC injection of ME7 prions, ( $N=5 / 6$ mice per group, $\mathrm{P}=0.0018$, Log-rank Mantel Cox Test). Weekly assessment of (B) Hind base of stance, (C) Right hind paw area and (D) Right Front paw intensity on the Catwalk XT automated gait analysis system following prion infection or in age-matched uninfected control mice. Points represent group mean and error bars $95 \%$ confidence interval as indicated; $C s f 1 r^{\mathrm{WT}}$ (black), $\operatorname{Csf1} \mathrm{r}^{\mathrm{AFIRE}}$ (red), uninfected (open circles), prion infected (closed circles), $\mathrm{N}=6$-10/group, Two-way ANOVA. * $\mathrm{P}<0.05 ; * * \mathrm{P}<0.005 ; * * *$, $\mathrm{P}<0.001 ; * * * *, \mathrm{P}<0.0001$.

Figure 2. Csf1r $r^{\mathrm{FIRE}}$ mice succumb to prion disease in the absence of microglia $(A)$ Immunohistochemical assessment of terminal prion-infected brain samples for $\mathrm{AlF}^{+}$microglia (red) and PSD95 (green), (B) assessed by \% area coverage in hippocampus CA1 ( $N=5 / 6$ mice per group, t-test). Gene expression analysis via RT-qPCR on naïve and terminal prion-infected brain samples for (C) Aif1, (D) Csf1r, (E) Itgam, (F) Cx3cr1, (G) Tmem119 and (H) Ccr2. Points show individual mice as indicated, $C s f 1 r^{\mathrm{WT}}$ (black), $C s f 1 r^{\Delta \mathrm{FIRE}}$ (red), naïve (open circles), terminal prion infected (closed circles), N=3-6 mice/group, bar = median, analysed by ANOVA. $*, \mathrm{P}<0.05 ; * *, \mathrm{P}<0.01 ; * * *, \mathrm{P}<0.0001$.

Figure 3. Microglia-deficiency effects on prion-specific vacuolation and prion accumulation.

(A) Hematoxylin and eosin stained brain sections, scale bars $=100 \mu \mathrm{m}$. (B) assessment of hippocampal CA1 pyramidal cell density and condition. (C) Lesion profile analysis of prioninfected brains. Each point represents the mean vacuolation score $\pm S E M, n=5-6$ mice/group, (D) Microarray analysis of relative gene expression for Prnp and Csf1r in hippocampus of naïve 
Csf1r ${ }^{\mathrm{WT}}$ (black, open circles) and Cs1fr ${ }^{\Delta \mathrm{FIRE}}$ (red, open circles) mice. (E) Western blot analysis of uninfected mice reveals similar levels of $\operatorname{PrP}^{\mathrm{C}}$ expression between $\operatorname{Csf} 1 \mathrm{r}^{\mathrm{WT}}$ and $\operatorname{Cs} 1 f \mathrm{r}^{\Delta \mathrm{FIRE}}$ mice, relative protein sizes indicated in kilodaltons $(\mathrm{kDa}) \mathrm{N}=3-6$ mice per group relative expression normalised to $C s f 1 r^{\mathrm{WT}}$ mice. (F) Terminal prion-infected $C s f 1 r^{\Delta \mathrm{FIRE}}$ brains (red, closed circles) display significantly reduced level of PK-resistant PrPsc compared to Csf1r ${ }^{\mathrm{WT}}$ $0.001 ; * * * *, \mathrm{P}<0.0001$

Figure 4. Microglial deficiency reduces terminal neuropathology. (A) Prion deposition, (B) GFAP accumulation and (C) CD44 accumulation are reduced in terminal prion-infected CSf1 $r^{\triangle F I R E}$ brains compared to $C s f 1 r^{\mathrm{WT}}$ brain assessed by relative intensity of DAB (brown) immunostaining, section lightly counterstained with hematoxylin (blue). $\mathrm{N}=4-6$ mice per group Students T-test); ${ }^{* *}, \mathrm{P}<0.01$, scale bars $=500 \mu \mathrm{m}$.

Figure 5. Microglia-deficiency alters astrocyte response to prions. Gene expression via RTqPCR for (A) Gfap, (B) Cd44, (C) Cd44v6, (D), Gbp2, (E) Psmb8 (F) Srgn, (G) Tnfa, (H) B3gnt5, (I) Ptx3, N=3-6 mice/group, ANOVA. * $\mathrm{P}<0.05 ; * *, \mathrm{P}<0.01 ; * * *, \mathrm{P}<0.001 ; * * * *, \mathrm{P}<0.0001$.

Figure 6. Microglial deficiency accelerates prion vacuolation but not brain or peripheral prion accumulation. (A) hemtoxylin and eosin stained images of the superior colliculus (brain area G3), scale bars $=100 \mu \mathrm{m}$. (B) The severity of the spongiform pathology (vacuolation) was assessed at $98 \mathrm{dpi}$ and plotted as lesion profiles. $\mathrm{N}=4$ mice/group, ANOVA. ${ }^{*}, \mathrm{P}<0.05 ;{ }^{* *}, \mathrm{P}<$ 
$0.01 ; * * * *, P<0.0001$. (C) Western blot analysis for PK-resistant PrPSc (D) Quantitation of PrPSc levels. (E) Relative prion seeding activity of 98 dpi brains was quantified in vitro by RTQulC. (F) Immunohistochemical analysis of prion accumulation in spleen disease-associated $\operatorname{PrP}(\operatorname{PrPd}$, Red) counterstained with hematoxylin (blue), scale bar $=100 \mu \mathrm{m}$.

Figure 7. Accelerated astrocyte activation and synaptic pruning in the absence of microglia. (A) Astrocyte activation and synaptic pruning were quantified by immunostaining for GFAP \& PSD95 and CD44. (B) bilateral GFAP \% area coverage (C) CD44 \% area coverage. Gene expression analysis via RT-qPCR for (D) Gfap, (E) Cd44, (F) Cd44v6 (G) assessment of synaptic pruning by \% total PSD95 colocalised with GFAP, bilaterally in area G3 superior colliculus. $N=4$ mice/group Student's T-test. **, $\mathrm{P}<0.01 ; * * * *, \mathrm{P}<0.0001$.

Figure 8. Increased unfolded protein response pathway is associated with earlier astrocyte

710 activation. (A) Western blot analysis of 98 dpi brain homogenates, probed for phosphorylated PERK (PERK-P), phosphorylated elF2 $\alpha$ (elF2 $\alpha-P), \beta$-actin and total PrP. ( $N=4$ mice/group, Students T-test) *, P < 0.05. (B) quantitation of elF2 $\alpha-P,(C)$ quantitation of PERK-P (D) Immunohistochemical analysis of PERK-P (green) and GFAP (violet) in G3 superior colliculus.

(E) Western blot analysis of terminal prion-infected brain homogenates probed for elF2 $\alpha-P$.

(F) Quantitation of elF2 $\alpha-P$ at the terminal stage of prion disesae ( $N=5-6$ mice/group, Students T-test). 
Bradford FIRE figure 1

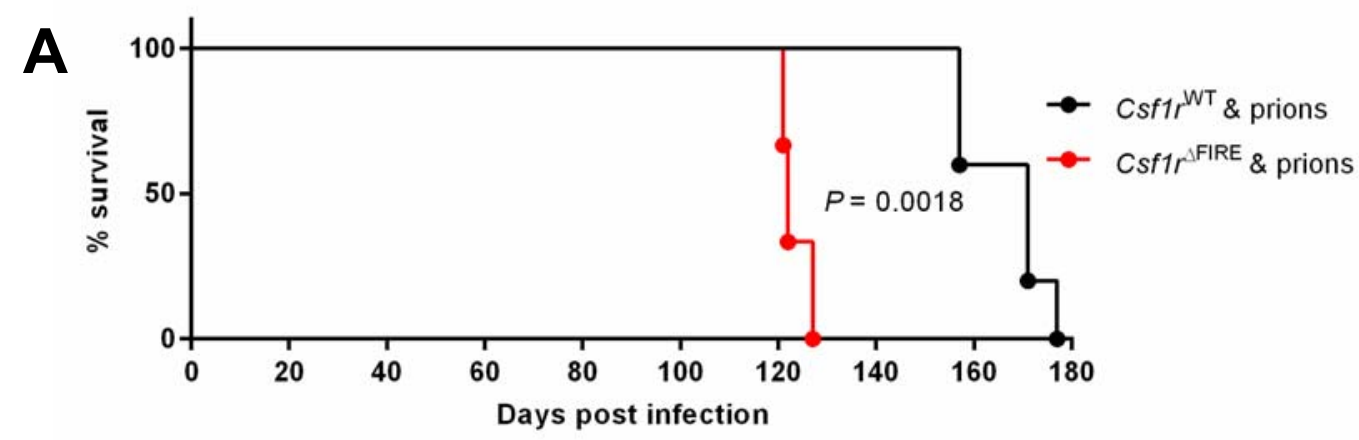

B

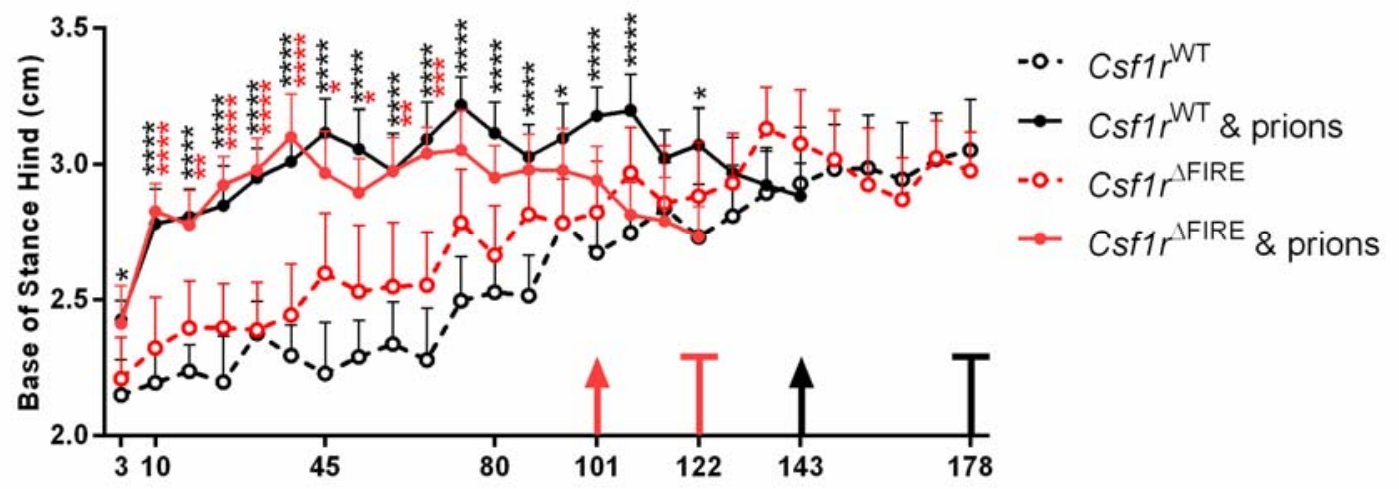

C
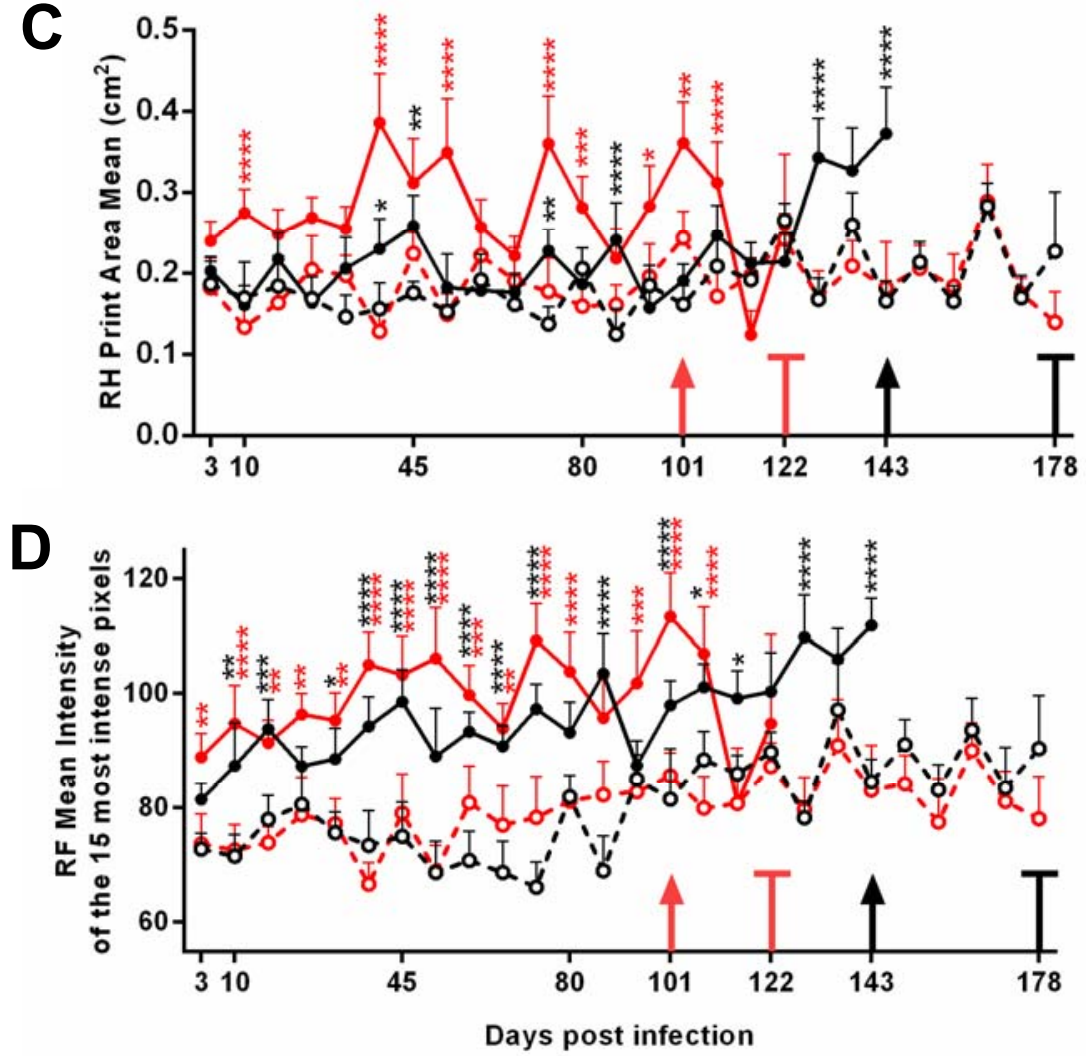
Bradford FIRE figure 2

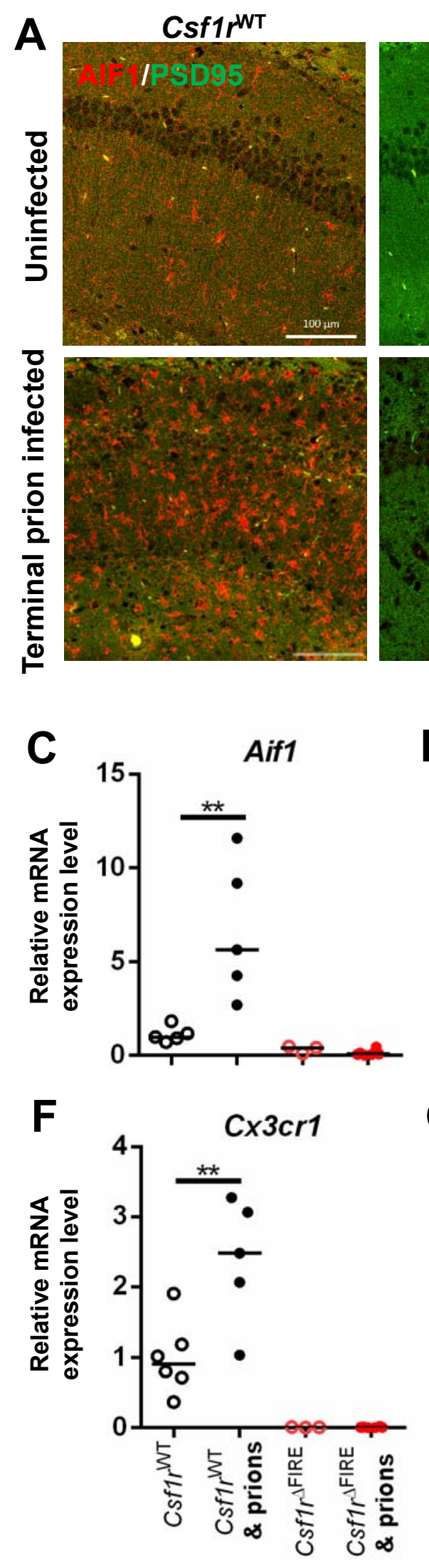

CSf1r $\triangle \mathrm{FIRE}$

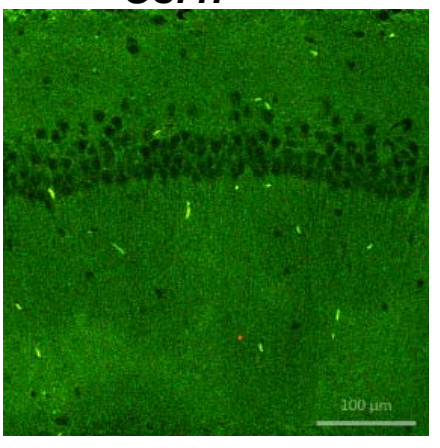

B
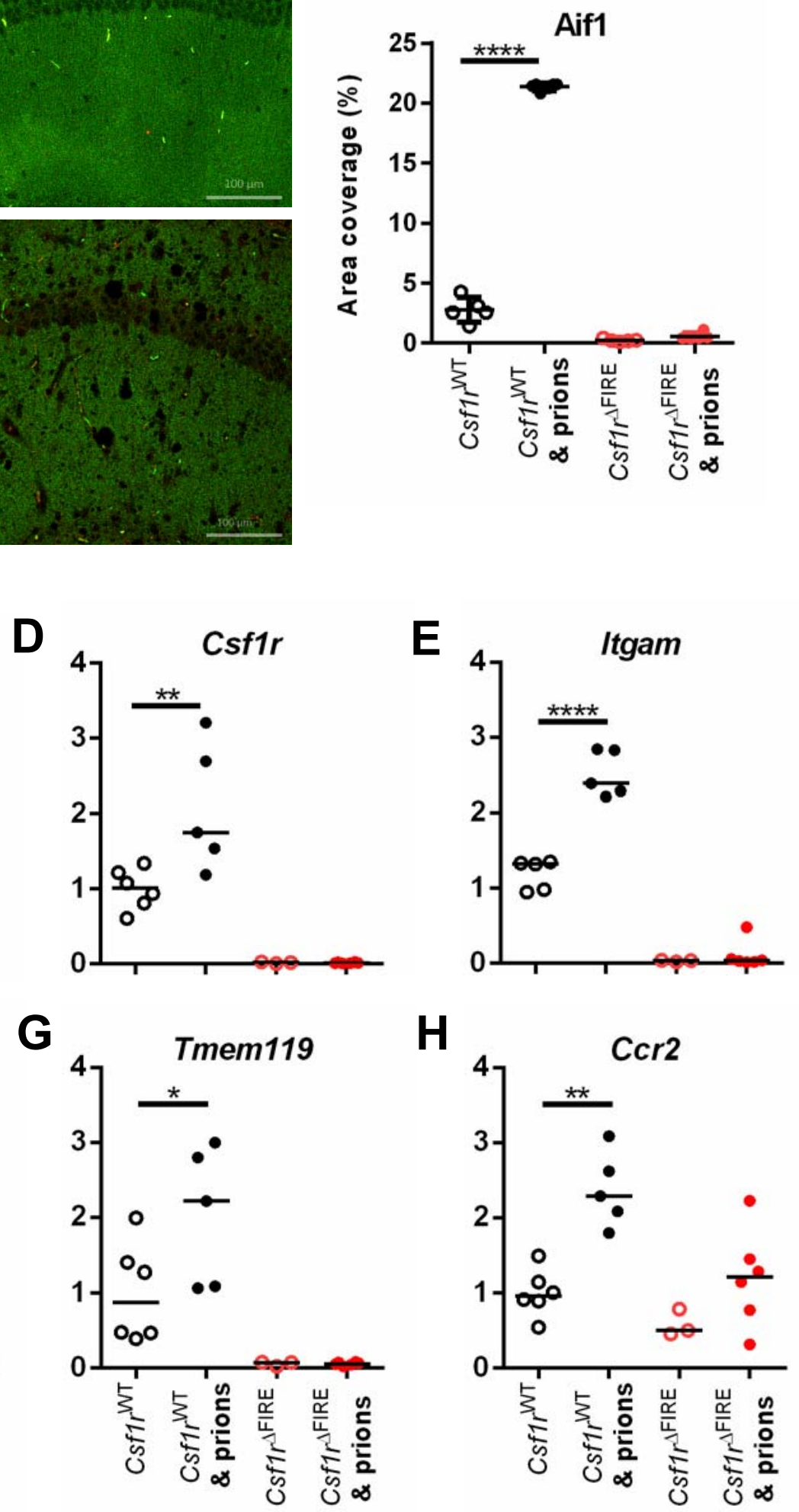


\section{Bradford FIRE figure 3}

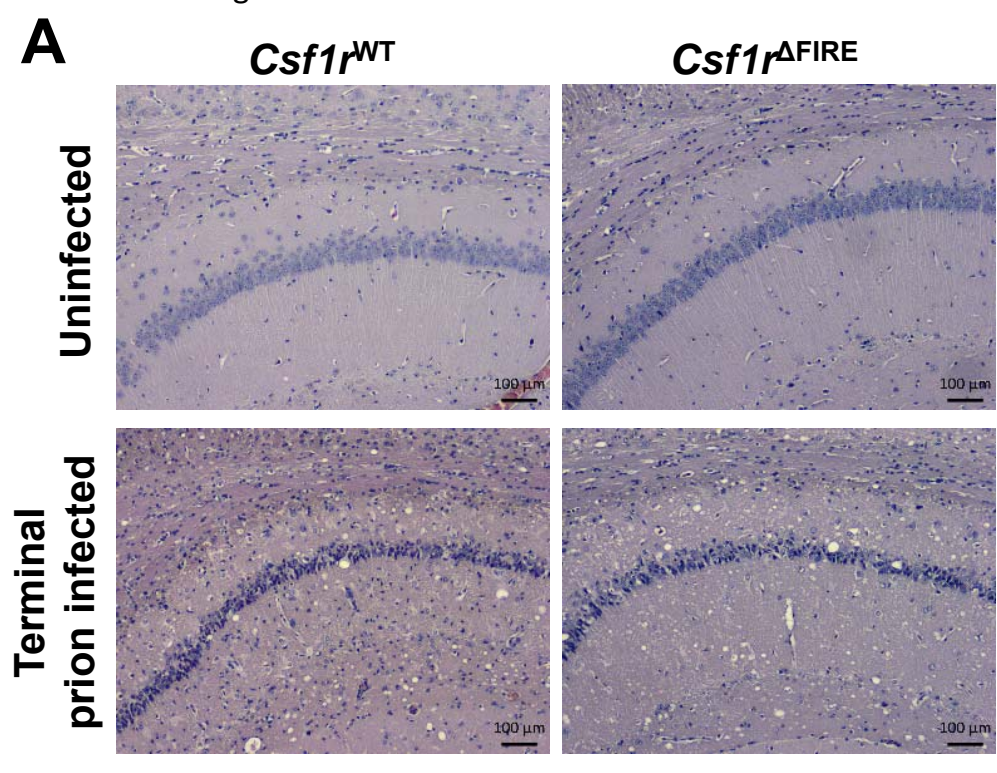

C

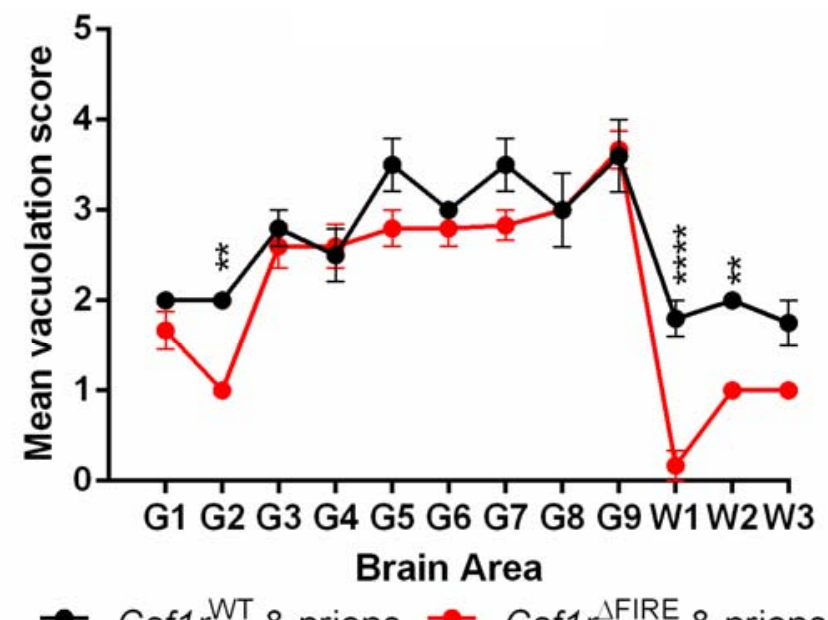

$\rightarrow$ Csf1 $r^{W T}$ \& prions $\rightarrow-C s f 1 r^{A F I R E}$ \& prions

$\mathbf{E}$

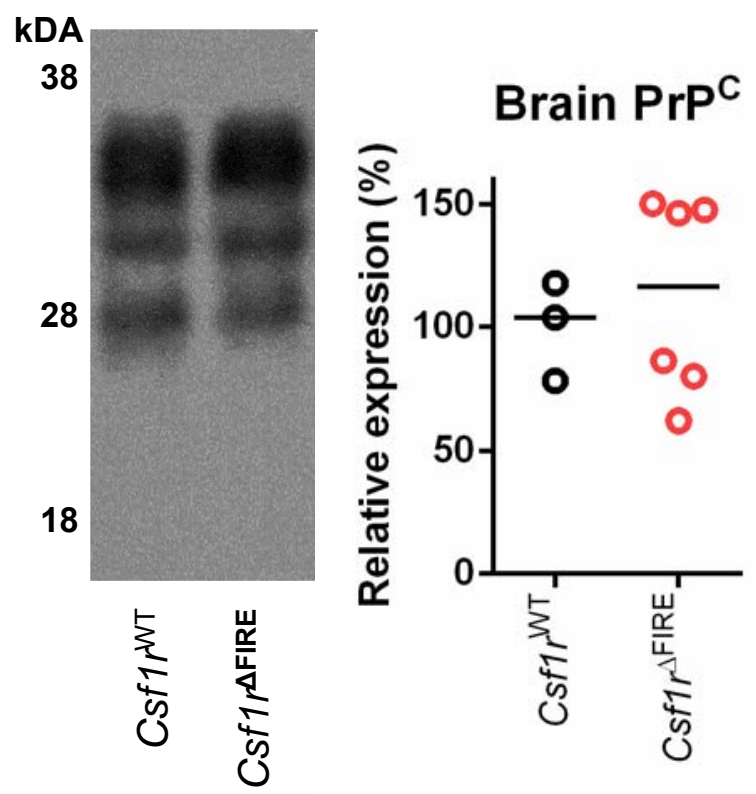

B Neuronal density

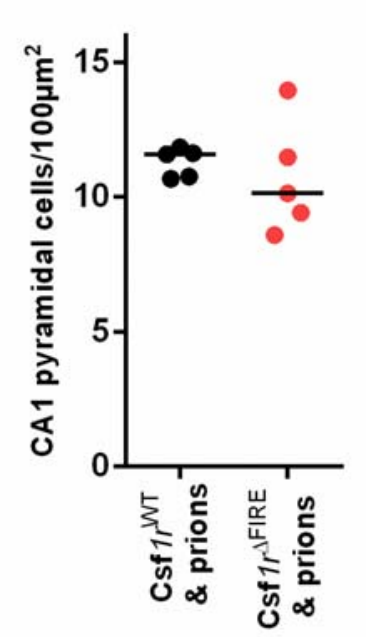

D
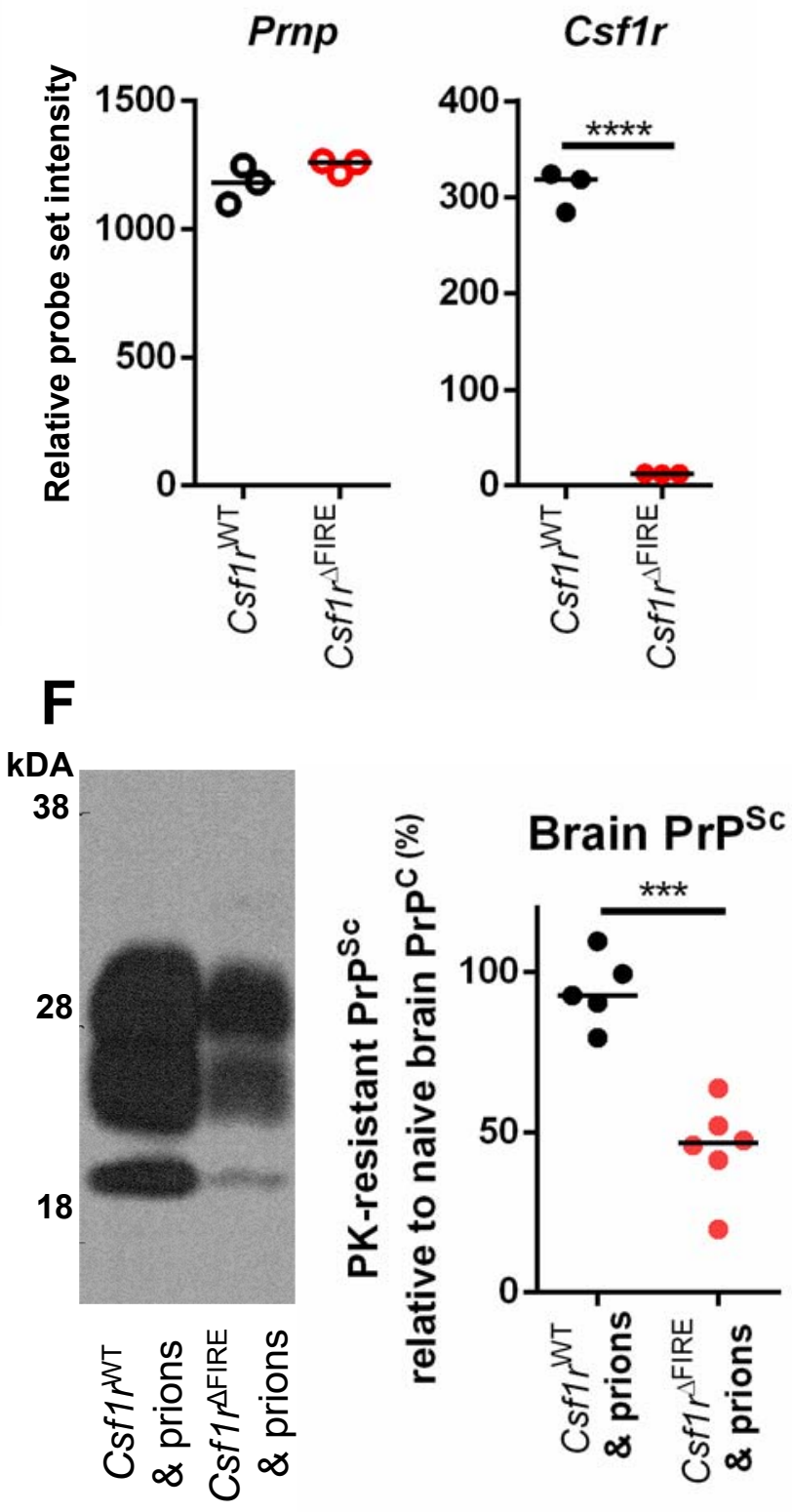
Bradford FIRE figure 4
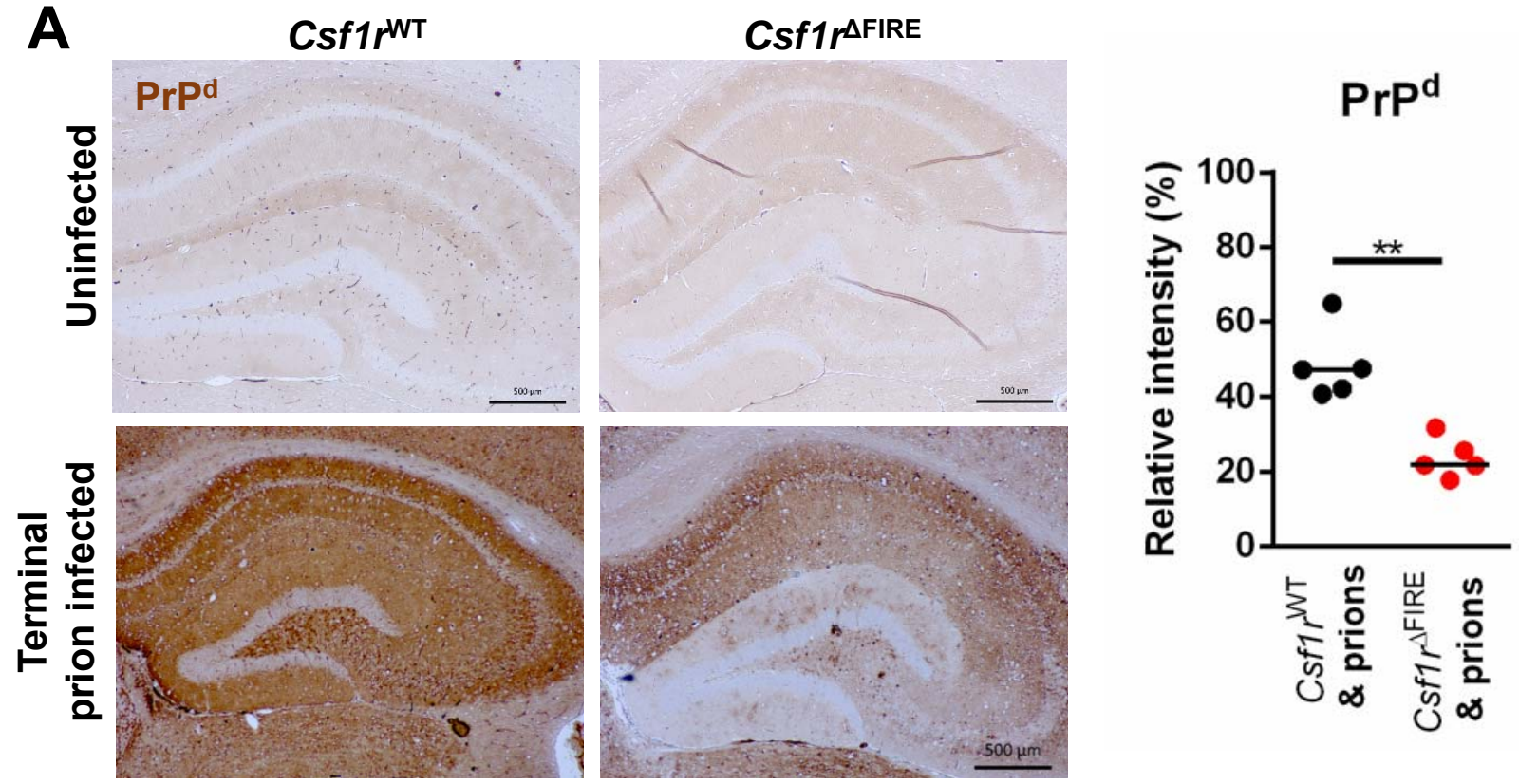

\section{B GFAP}
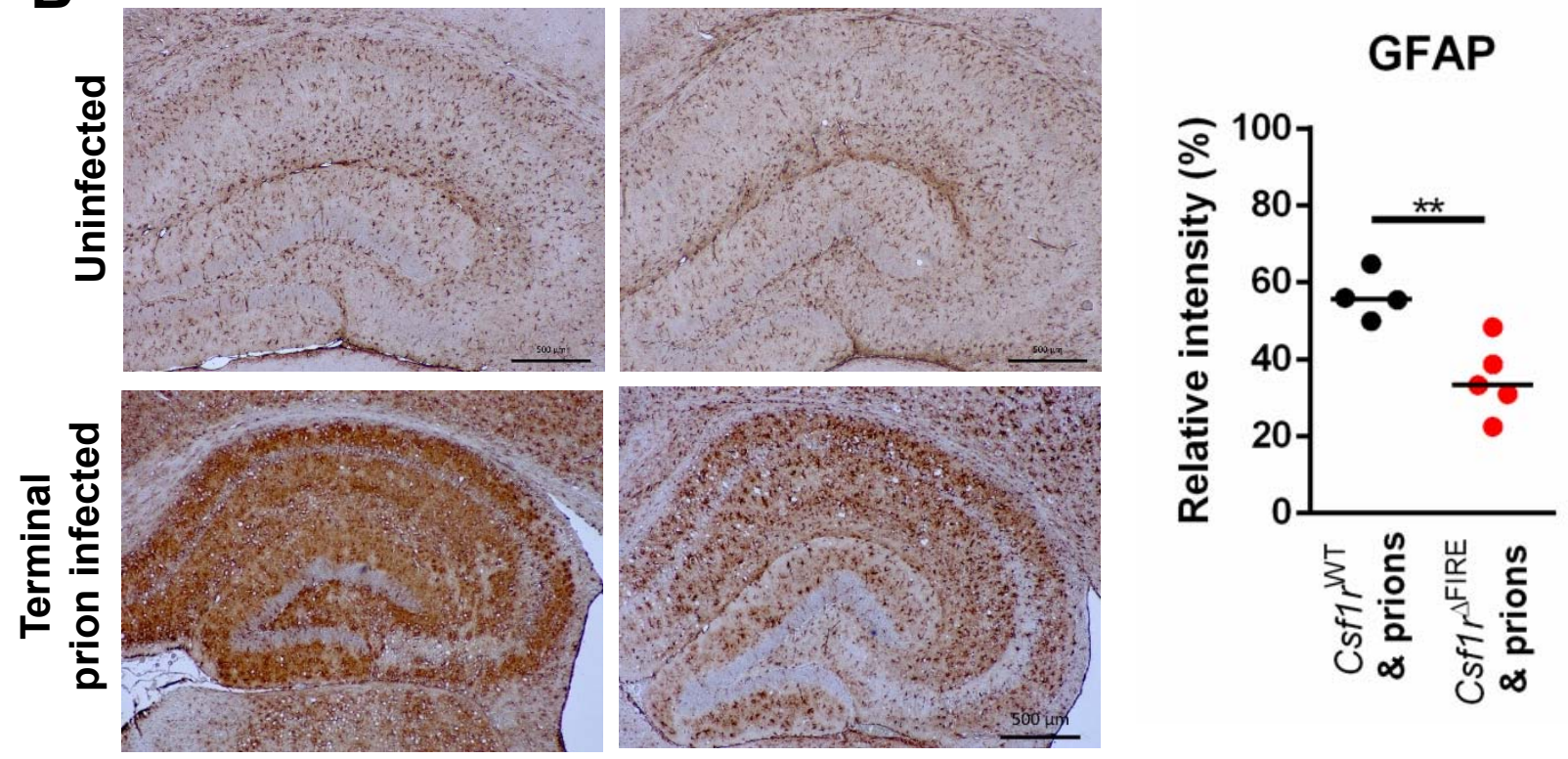

\section{CD44}
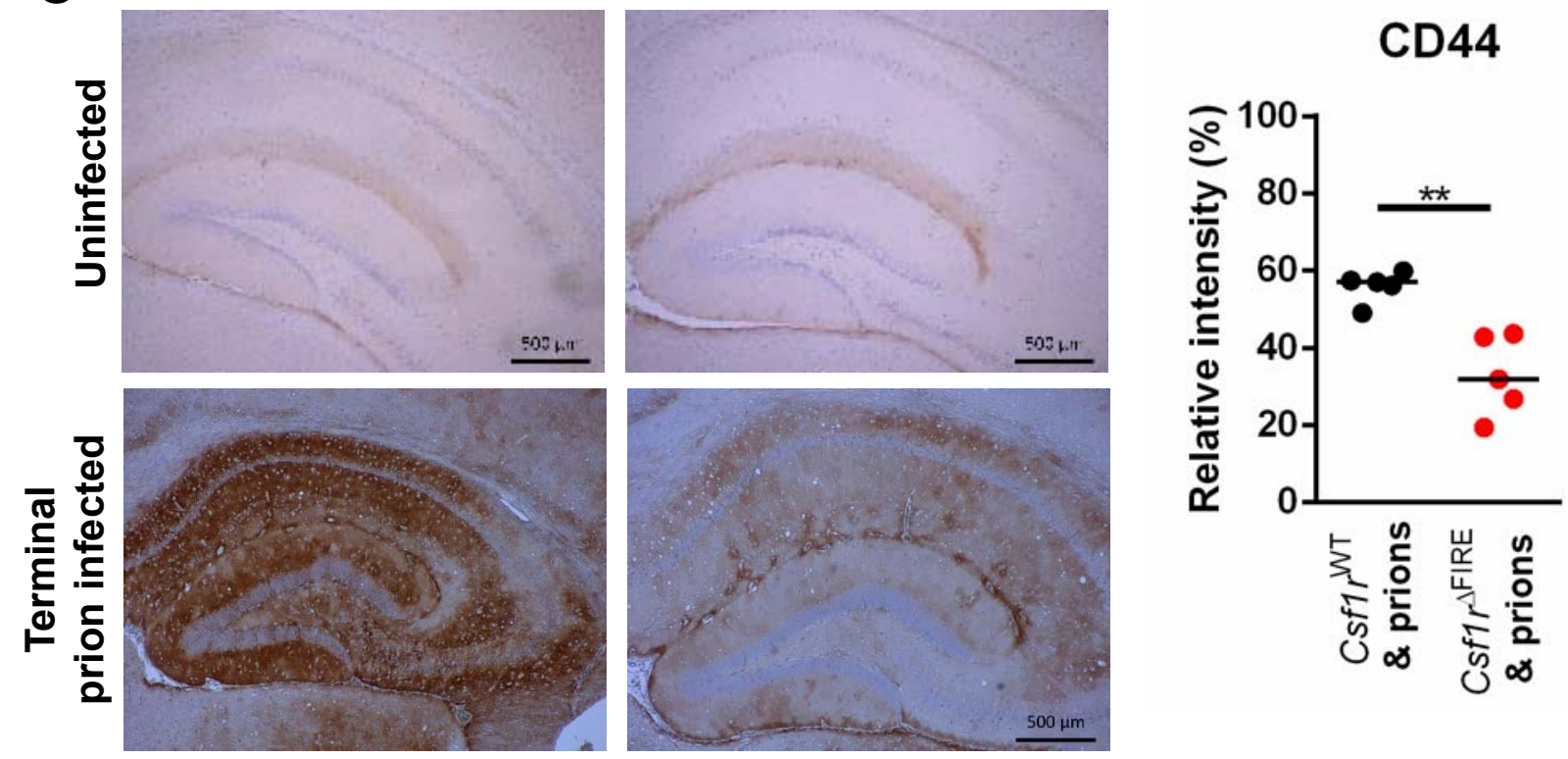
Bradford FIRE figure 5

A

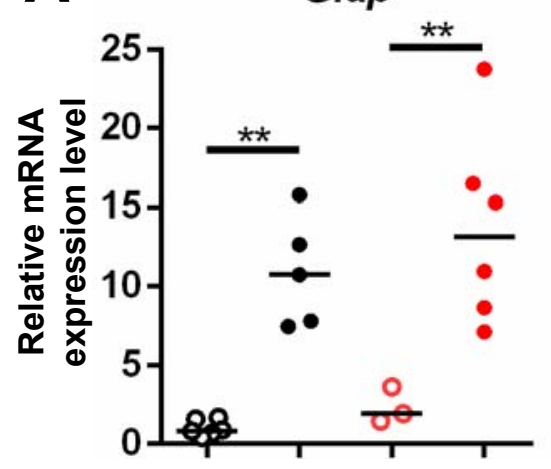

D

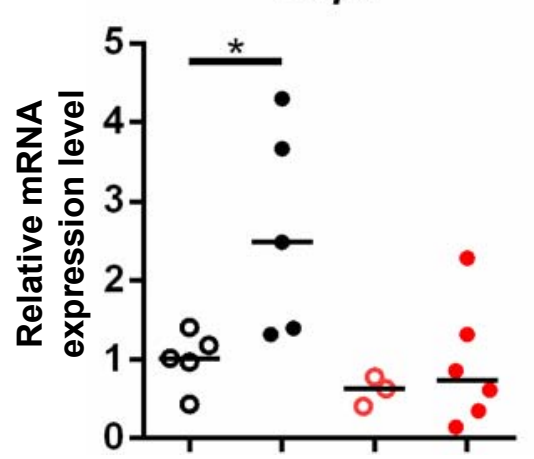

G Tnfa

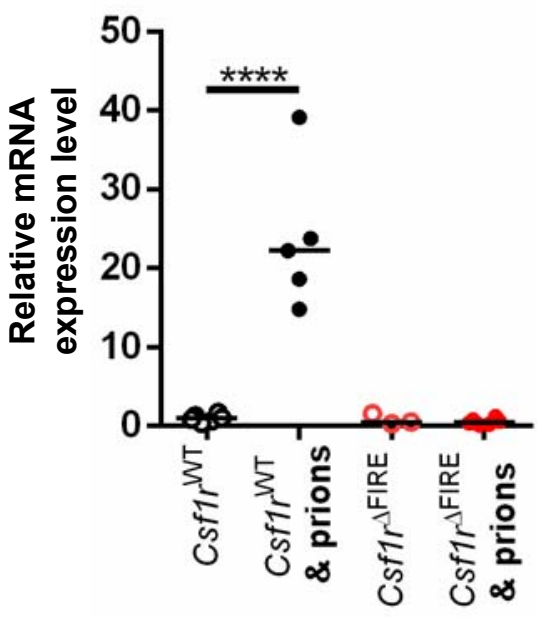

B

Cd44

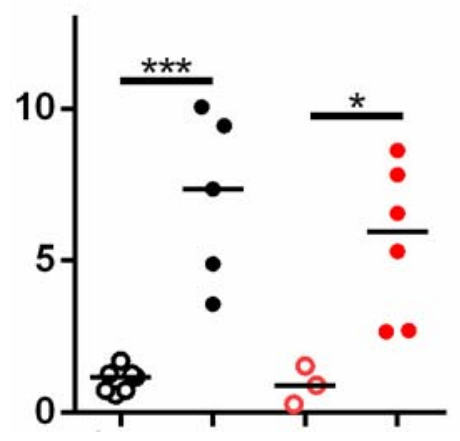

E

Psmb8

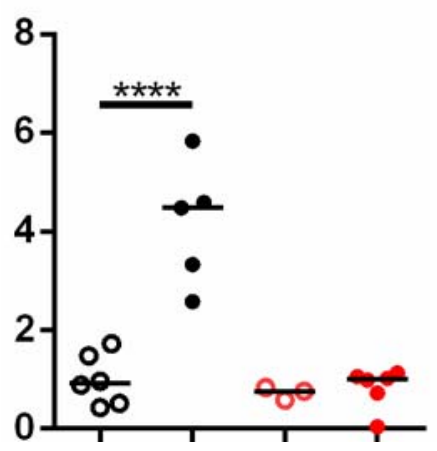

H

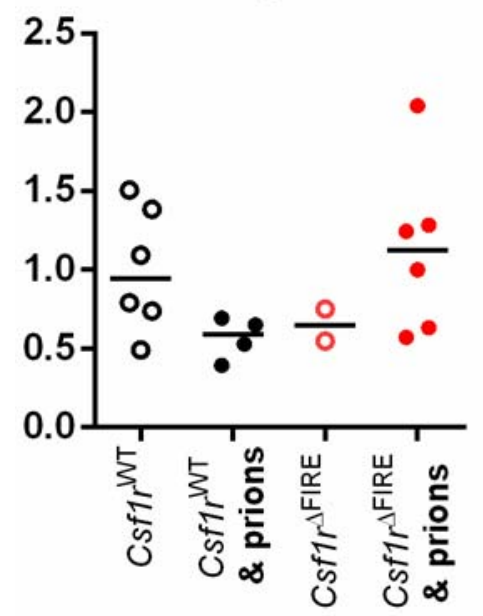

C Cod4v6

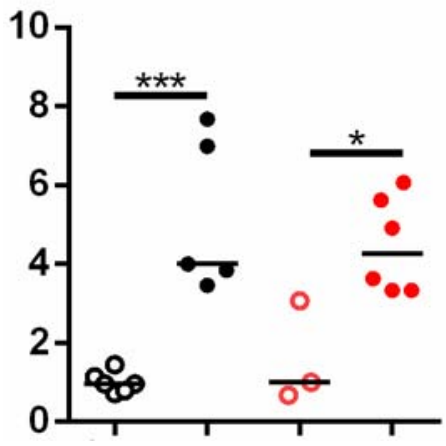

F

Srgn

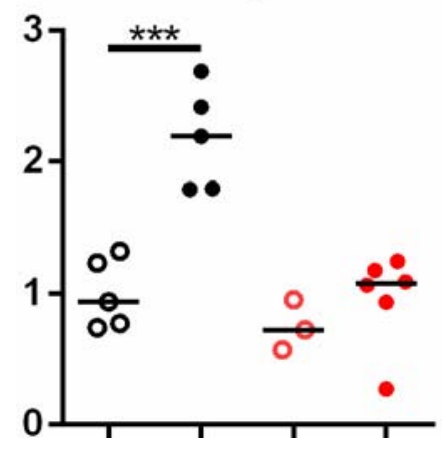

Ptx 3

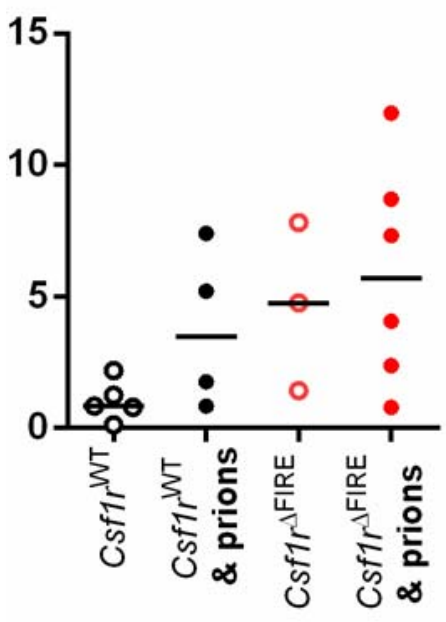


A

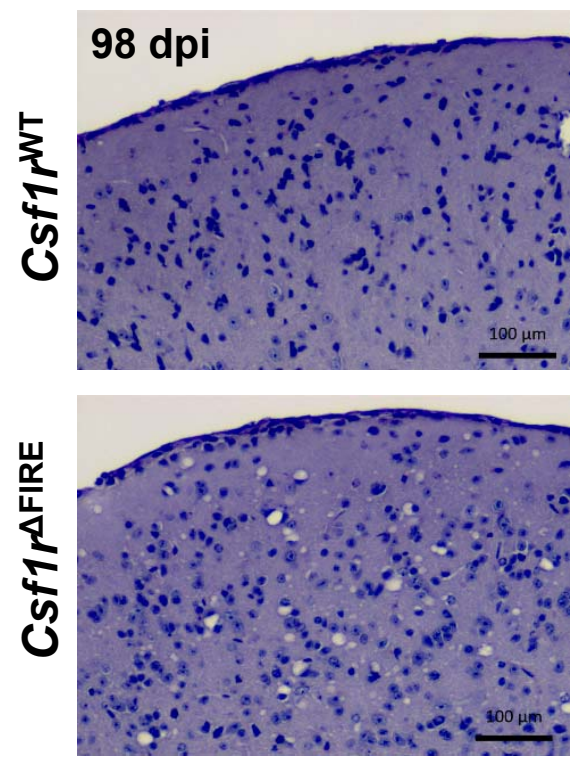

C
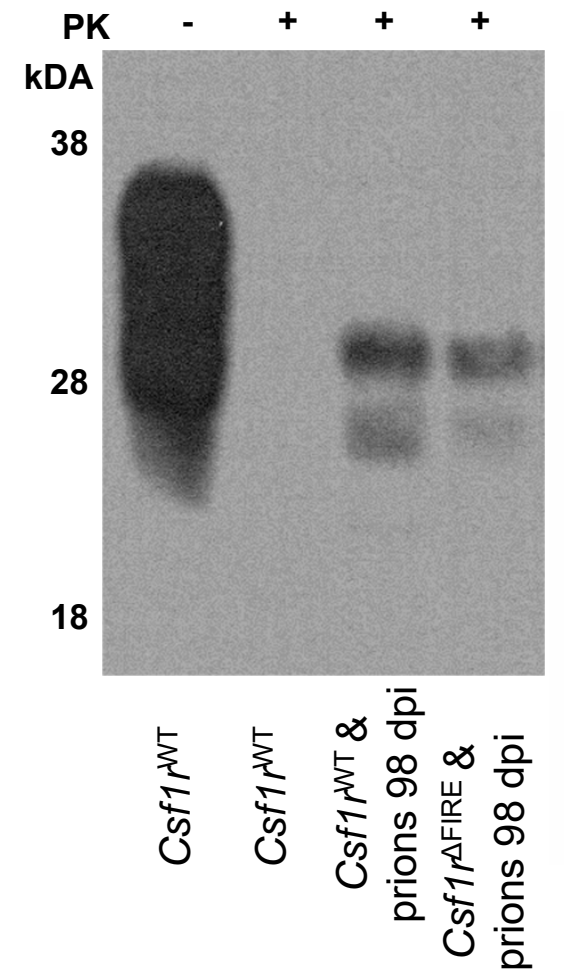

F 98 dpi

\section{Csf1rWT}

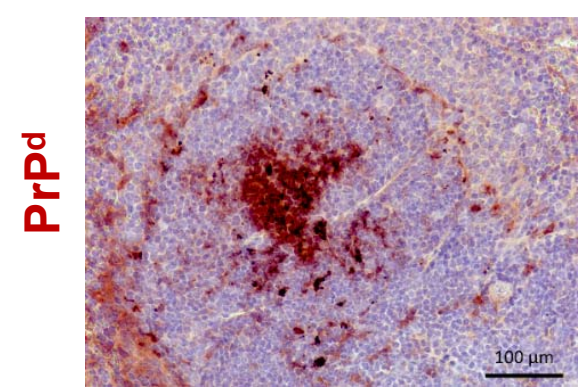

B

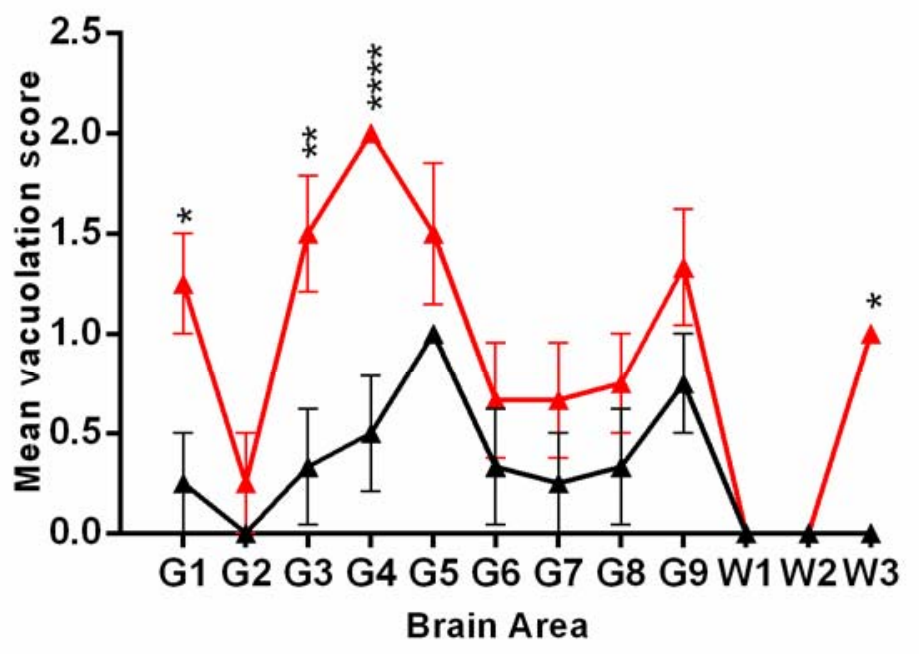

$\rightarrow \operatorname{Csf1r}^{\mathrm{WT}}$ \& prions $98 \mathrm{dpi} \nrightarrow C s f 1 r^{\mathrm{SIRE}}$ \& prions $98 \mathrm{dpi}$
D

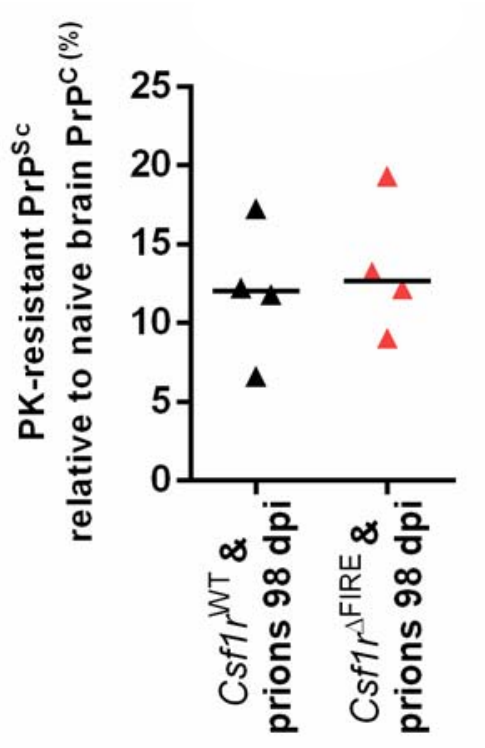

E

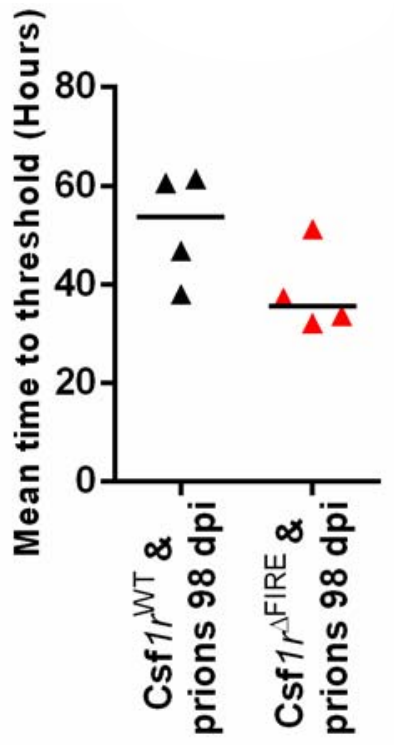

\section{Csf1r $^{\Delta F I R E}$}

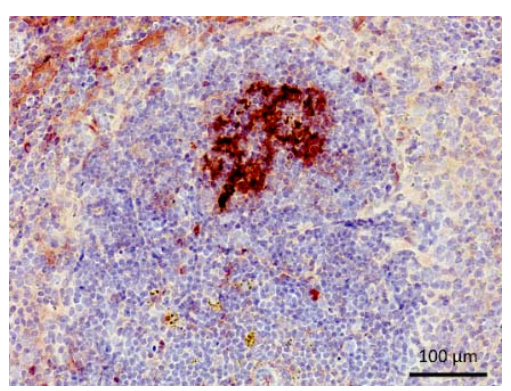


Bradford FIRE figure 7

\section{A 98 dpi}

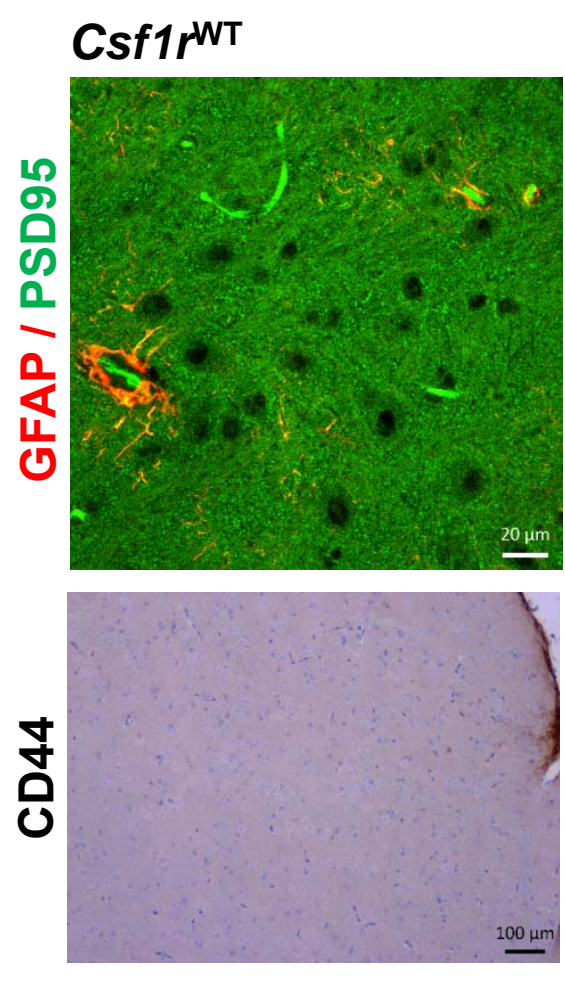

\section{Csf1r $\mathrm{PFIRE}$}

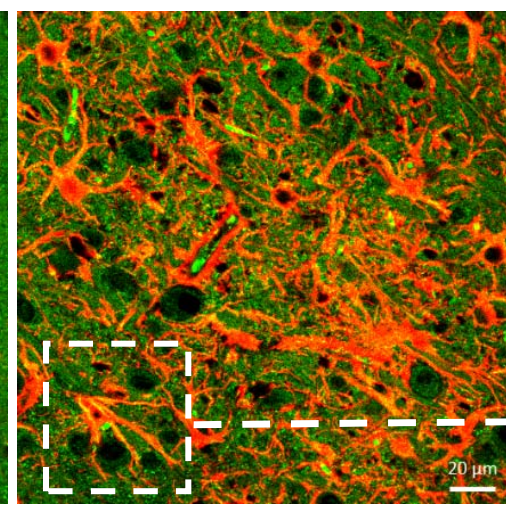

B

GFAP
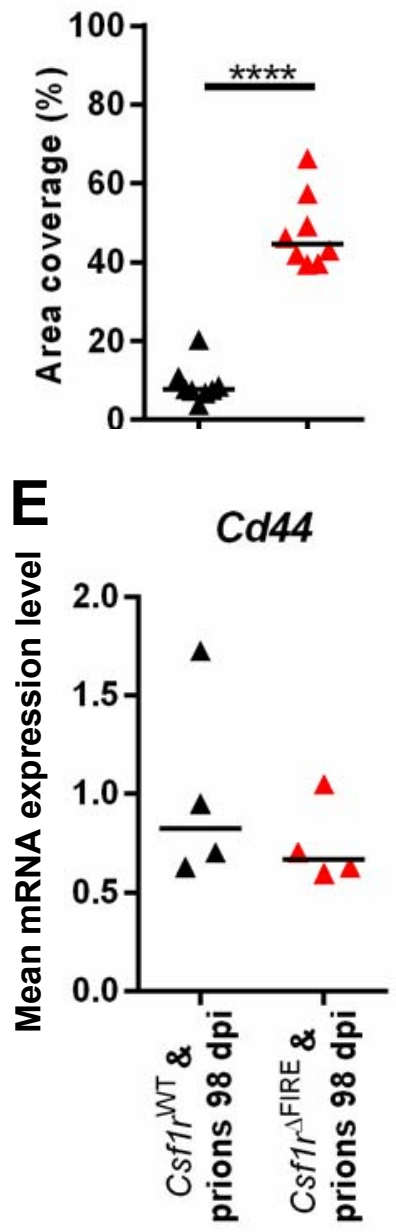
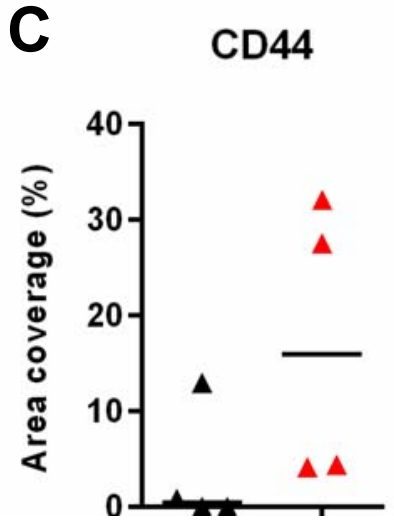

F

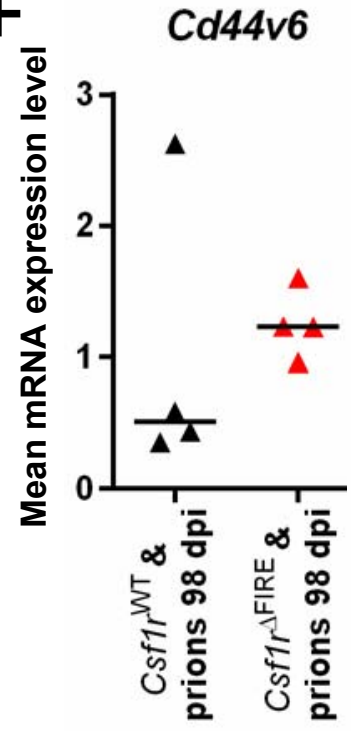

\section{Csf1r $\mathrm{PFIRE}$}

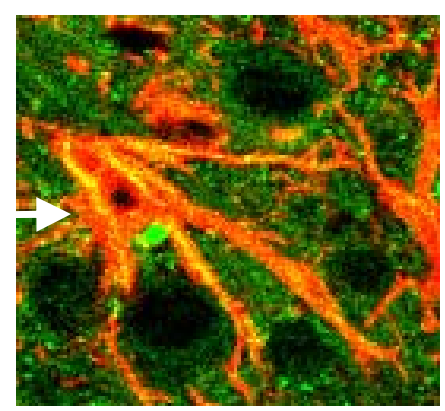

D

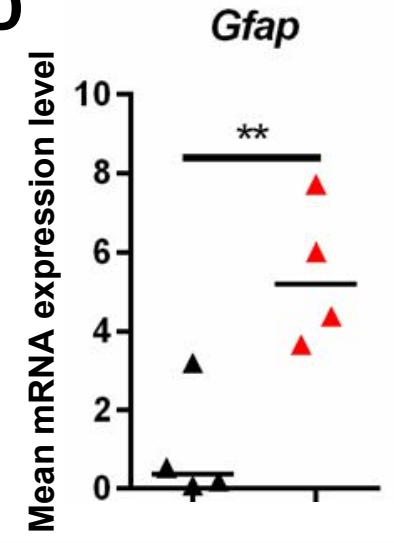

Pruned synapses

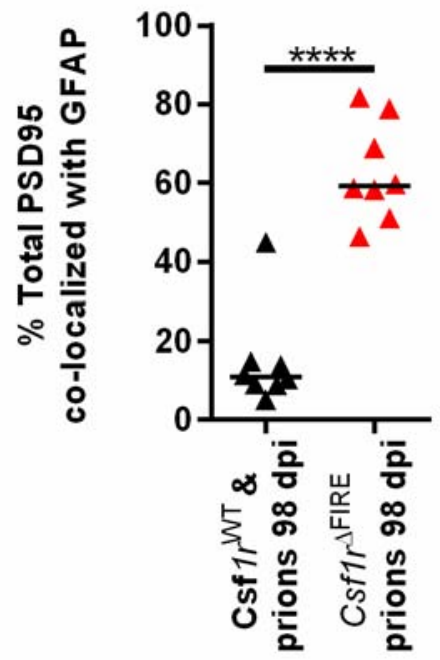




\section{A Prions 98 dpi}
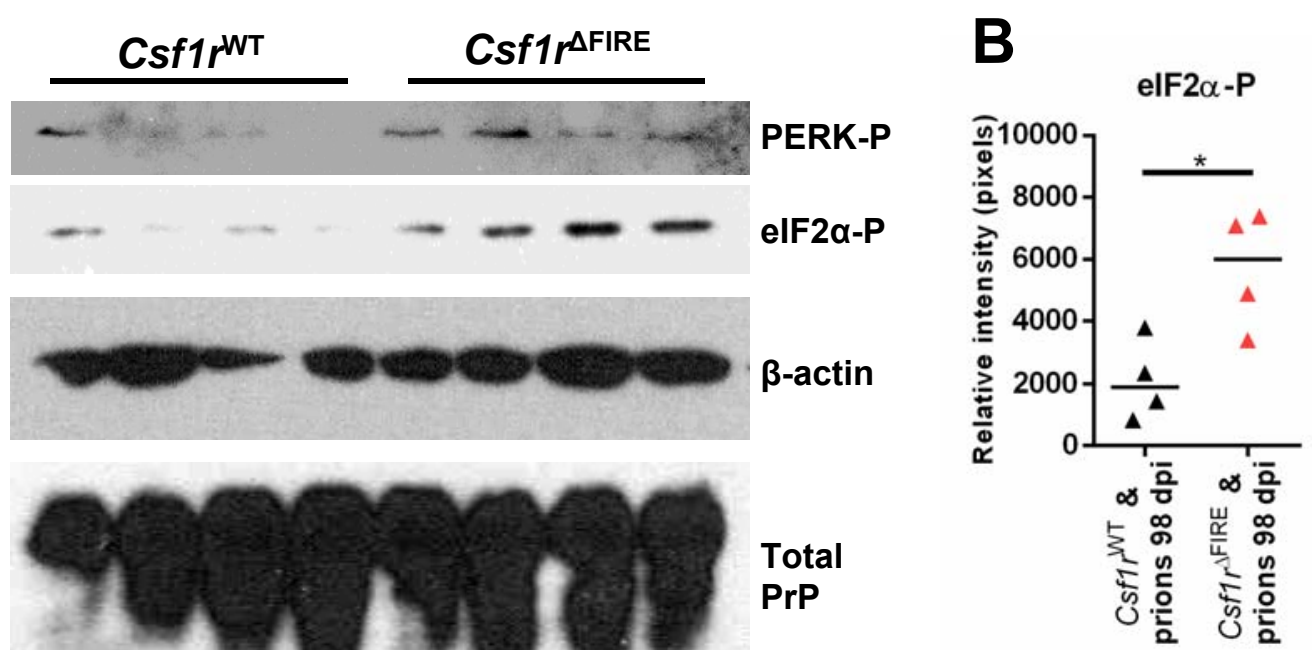

Bradford FIRE figure 8

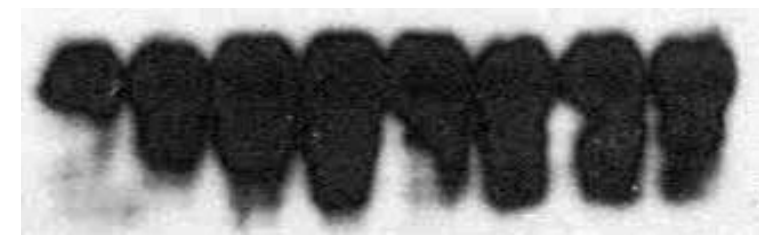

Total

PrP

D
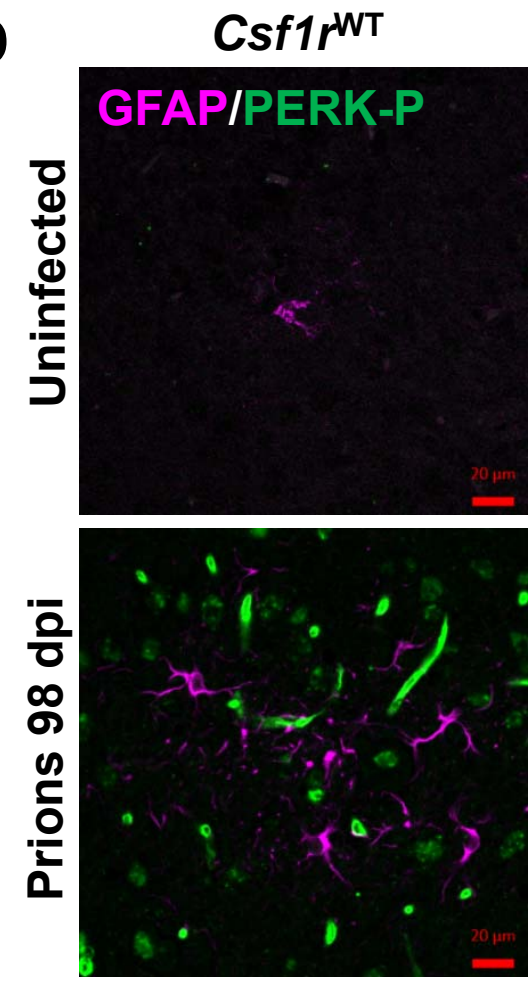

E Terminal prion disease

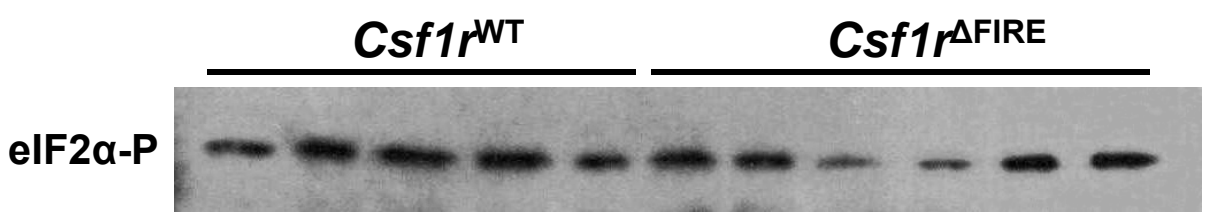

\section{Csf1r ${ }^{\Delta \mathrm{FIRE}}$}

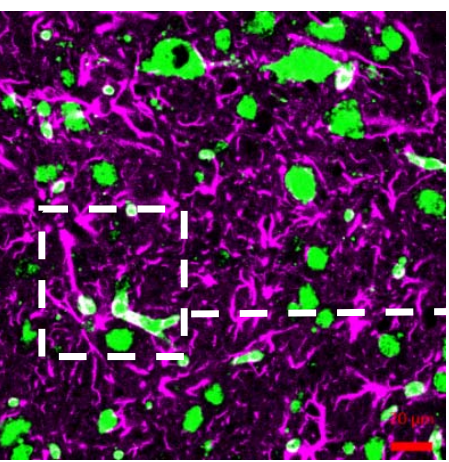

$\mathbf{F}$ elF2 $\alpha-P$

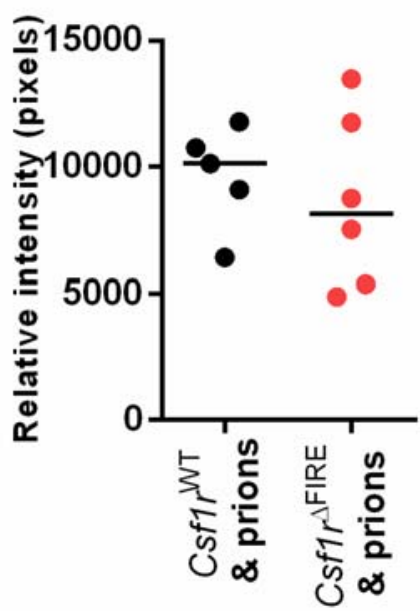

